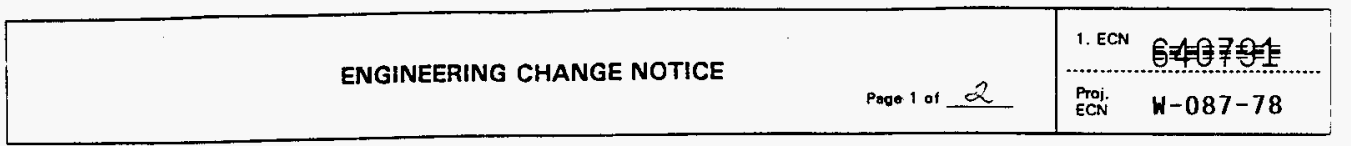

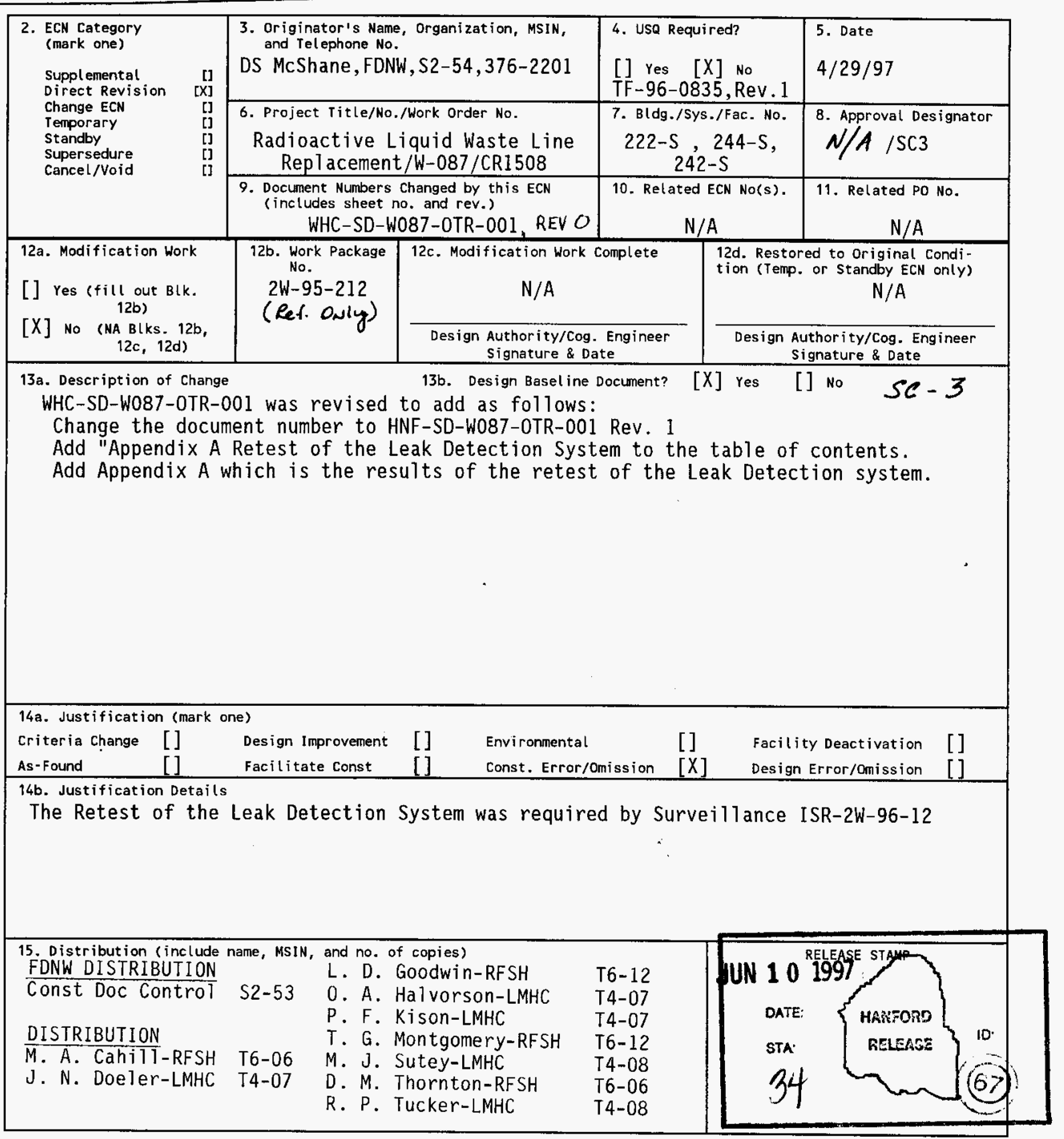




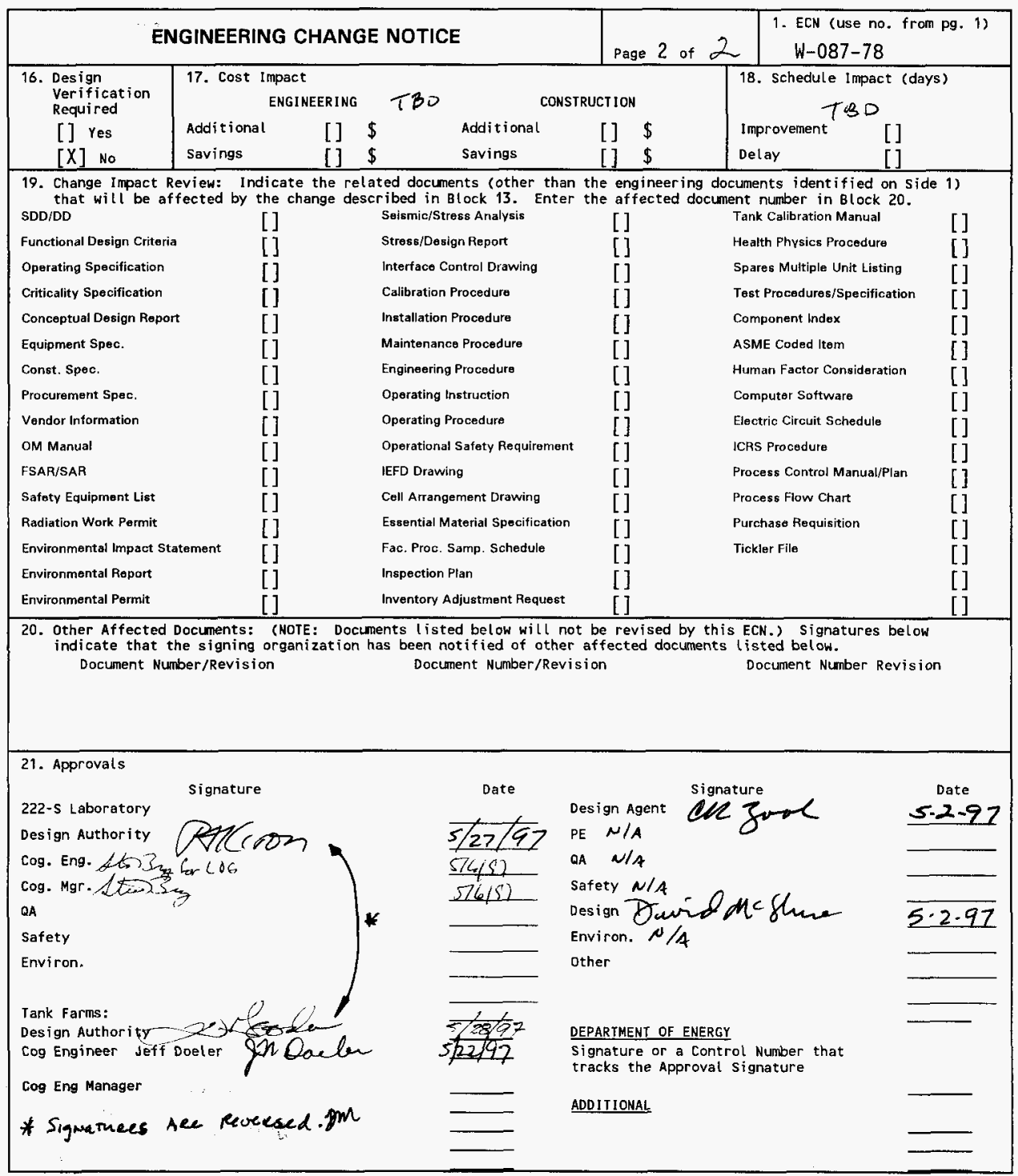




\title{
W-087 Operational Test Report
}

A. W. Joshi

Fluor Daniel Northwest, Richland, WA 99352

U.S. Department of Energy Contract DE-AC06-96RL13200

\author{
EDT/ECN : W-087-78 \\ Org Code: 476 \\ B\&R Code: $39 E W 21303$ \\ UC: $N / A$ \\ Charge Code: CR1508 \\ Total Pages: 52
}

Key Words: Operational Test Report for Project W-087, an underground transfer line from 219 S to 2445 .

Abstract: An Operational Test Report for the controls and pumps of an underground transfer line.

TRADEMARK DISCLAIMER. Reference herein to any specific commercial product, process, or service by trade name, trademark, manufacturer, or otherwise, does not necessarily constitute or imply its endorsement, recommendation, or favoring by the United States Government or any agency thereof or $i$ ts contractors or subcontractors.

Printed in the United States of America. To obtain copies of this document, contact: Document Control Services, P.O. Box 950, Mailstop H6-08, Richland WA 99352, Phone (509) 372-2420; Fax (509) 376-4989.

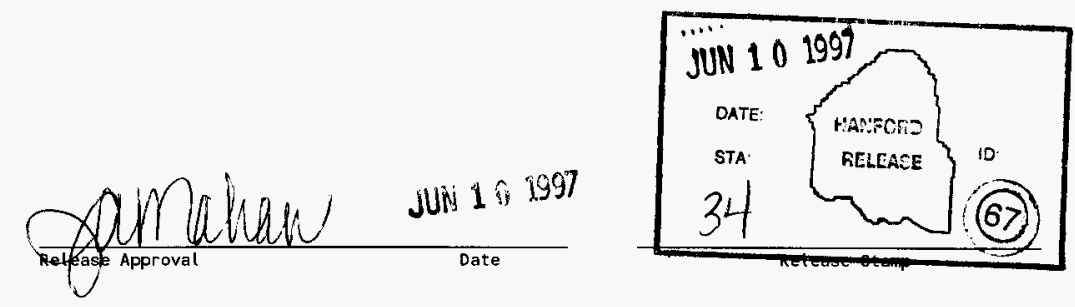

\section{Approved for Public Release}




\section{RECORD OF REVISION}

(2) Title

W-087 Operational Test Report

CHANGE CONTROL RECORD

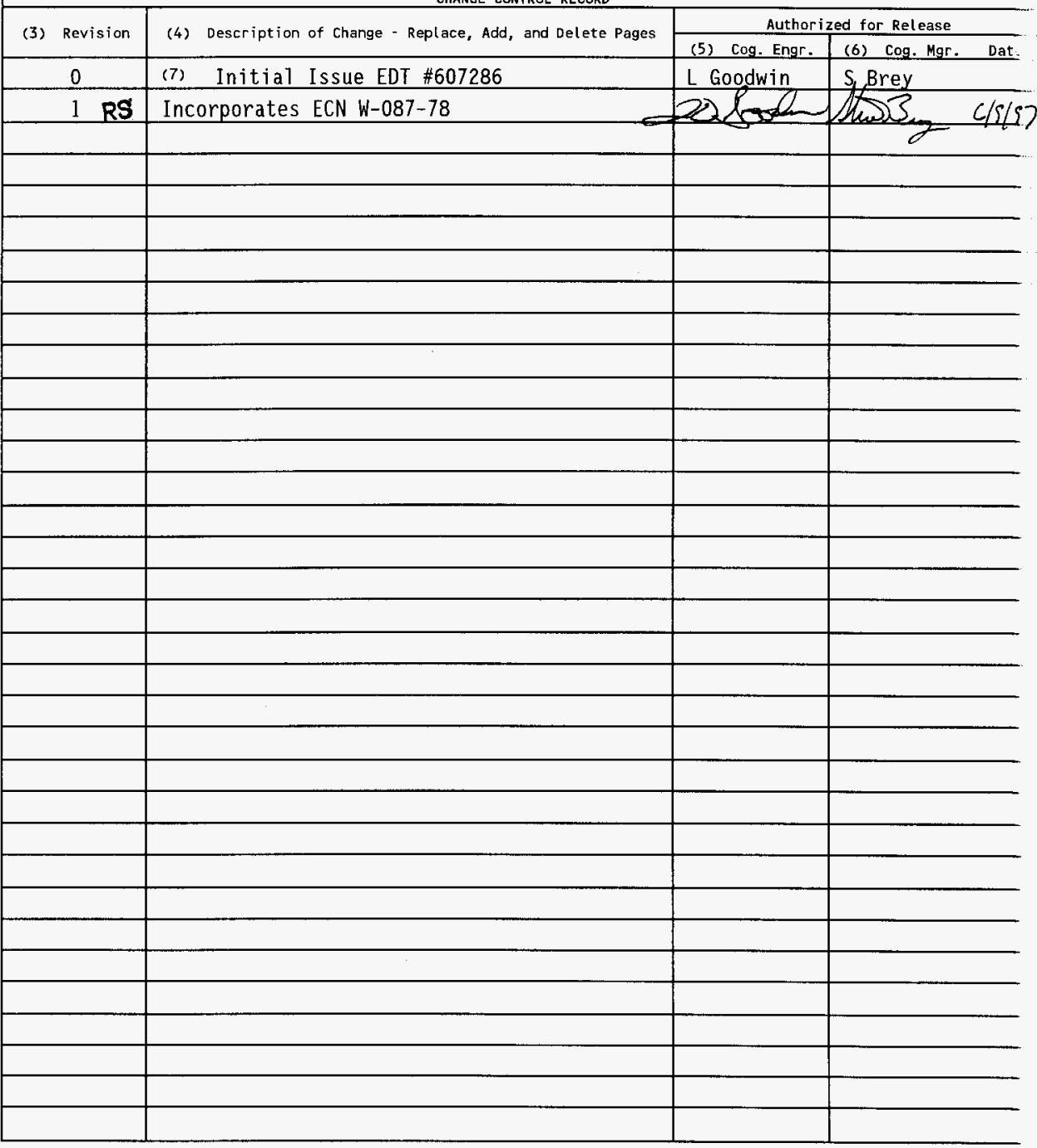


TEST TITLE Radioactive Haste Transfer Line Equipment, Leak Detection System, and Transfer Pump

LOCATION 219-5, 242-5, 244-5, 222-5 ROOM 3B

PROJECT NUMBER H-087 HORK ORDER

PROJECT TITLE Radioactive Waste Transfer Line Replacement

\author{
Prepared By \\ ICF Kaiser Hanford Company \\ Richland, Washington \\ For Westinghouse Hanford Company \\ Subcontract WHC 380393
}

PROCEDURE APPROVAL

ICF KAISER HANFORD COMPANY (ICF KH)

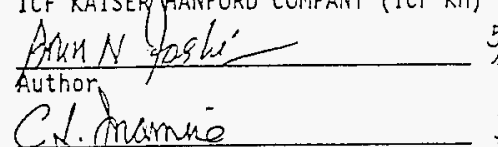

$\frac{5 / 10196}{\text { Date }}$

$\frac{\text { Rohect } B 21 / 20000}{\text { Technical Dodtinents }} \frac{5-10-96}{\text { Date }}$

Checkomer

$\frac{5 / 10 / 96}{\text { Date }}$

Safety

Date

$\frac{\text { EA }}{\text { Environmental }}$

Hestinghouse Hanford Company (hHC)

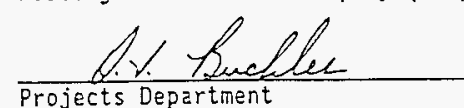

Date
$\frac{5-10 \cdot 96}{\text { Date }}$

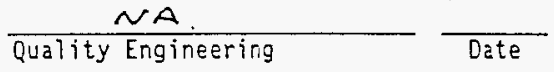

$\frac{\text { ST }}{\text { Safety } 6 E \text { EDT } 615120}$

SEE EDT $615 / 20$

Analytical Services
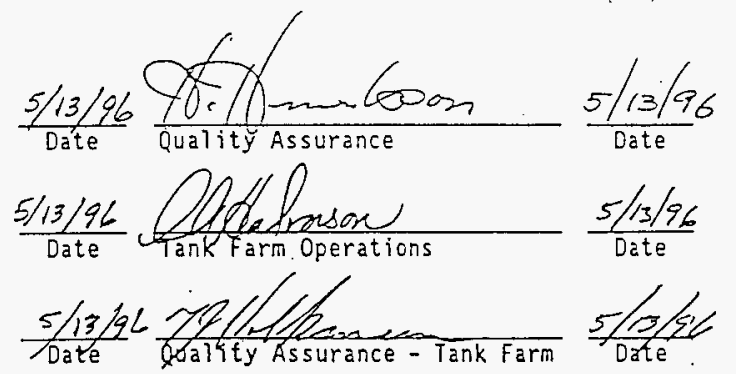
EXECUTION AND TEST APPROVAL

EXECUTED BY

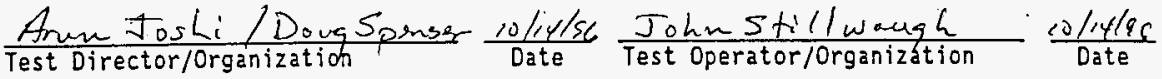

$$
\begin{aligned}
& \frac{\text { Cliff Larsen } A I}{\text { Recorder/Organization }} \frac{\text { ololls6 }}{\text { Date }}
\end{aligned}
$$

WITNESSES

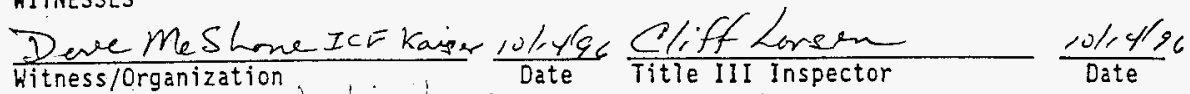

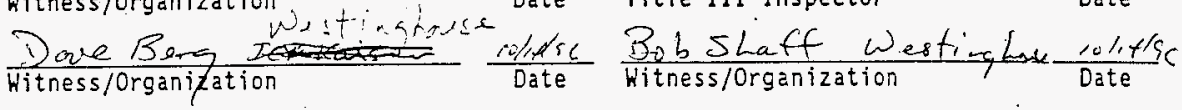

ATE APPROVAL

ICF Kaiser Hanford Company (ICF KH)

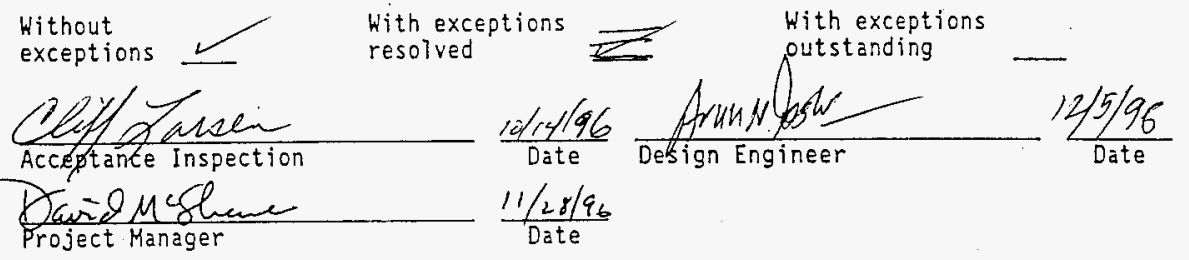

TEST APPROVAL AND ACCEPTANCE

Westinghouse Hanford Company (tHC)

Without With exceptions exceptions resolved
With exceptions outstanding

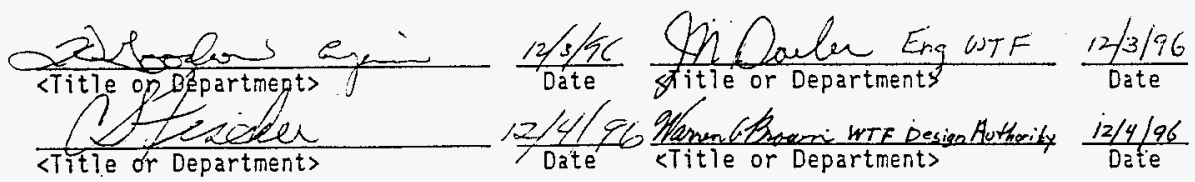

Dos 2 U Guidason $12 / 4 / 96$

D. OP a MGR \& SHIFTMGR

- 2.-

HNF-SD-W087-0TR-001

Rev. 1

$4 / 28 / 97$ 
TITLE/PROCEDURE APPROVAL

TABLE OF CONTENTS

TABLE OF CONTENTS

\section{1}

PURPOSE

REFERENCES

2

RESPONSIBILITIES

CHANGE CONTROL

EXECUTION

EXCEPTIONS

7 PREREQUISITES, EQUIPMENT/IHSTRUMENTS, COMPONENT LOCATIONS, AND ABBREVIATIOHS

LEAK DETECTION AND HONITORIKG SYSTEM

TRANSFER PUMP PI SPEED CONTROL.

MOTOR OPERATEO VALVES HV-PI AND HV-305

APPENDIX A Retest of Leak Dectection

NOTE: At completion of test, enter pages added during performance of test. to this Table of contents. 
This Acceptance Test Procedure/Operational Test Procedure (ATP/OTP) has been prepared to demonstrate that the Electrical/Instrumentation and Mechanical systems function as required by project criteria and to verify proper operation of the integrated system including the interlocks.

The equipment to be tested includes the following:

a. Leak detection system operation and controls.

b. Electrical interlocks.

c. Transfer pump operation.

d. Vacuum breaker system interlocks.

The following tests will ensure the operation of the equipment used in support of radioactive 7 iquid transfer from 222-S Laboratory Facility to 219-5, 242-5, and then to $244-5$. This test will include checks on associated annunciator systems.

The leak detection system uses 3 leak detector elements (LDEs) to monitor the entire length of pipe installed between 219-5 and 244-5.
a. LDE-306A monitors approxinately 925 feet of pipe between $219-5$ and LDE-306A.
b. $\quad L D E-306 B$ monitors approximately 1000 feet of pipe between $1 D E-306 \mathrm{~A}$ and LDE-306B.
c. LDE 305 C monitors approximately 1005 feet of pipe between $L D E-306 B$ and LDE-305C.

The leak detectors are connected to leak detection panels mounted locally. The signals are transmitted to control panels located at 219-S, 242-S and 244-5. Leak detection annunciation is provided at 219-S, 222-S Rocm 3B, 242-5 and 244-S; and has capability to connect to Central Alarm Surveillance System (CASS).

The leak detection signals are connected to the transfer pump interlock. The pump interlocks are arranged such that evidence of leak in any section of the pipe, or a pump diaphragm leak, or a manual override by the DENY pushbutton will stop pump operation.

The transfer pump is air operated diaphragm type, operated by pneumatic controlier. Air supply to the pump is controlied by an in line motor operated valve. If leak detection system is activated, the pump interlock circuit will prevent pump operation. In addition, if pump diaphragm should leak, pump interlock circuit will prevent pump operation. 
2 REFERENCES

\subsection{DRAHINGS}

2.1.1 Project $W-087$ Drawings

$\mathrm{H}-2-820841$, Sh $\mathrm{I}$ and 2 , Rev 0 H-2-820842, Sh 1, Rev. O H-2-820843, Sh 1, Rev. O $\mathrm{H}-2-820848 \mathrm{Sh}$ 1, Rev $\mathrm{O}$
Instrumentation Conn. Diagrams

242-S Panel A Hodifications

242-5 Panel A Interconn. Diagram

Leak Detection, Elem. Diagram

2.1.2 Project $W-178$ Drawings Showing Interface with Project $W-087$

H-2-825536, Sh 1, Rev. 0 $\mathrm{H}-2-825549$ Sh 1, Rev 0 $\mathrm{H}-2-825550 \mathrm{Sh}$ 1, Rev $\mathrm{O}$
Cell A \& Operating Gallery

Leak Detection Panel IP?

Control Panel IP3

\subsection{SPECIFICATIONS}
H-087-Cl, Rev 0
W-087-C2, Rev 0
Construction Specification
Construction Specification

\subsection{VEHDOR INFORMATION}
a. Leak detection syster (B/W Magnatek): VI 22687, Supplement No. 8.
b. Diaphragm pump and diaphragm leak detection and speed control unit (Sandpiper): VI 22687, Supplement No. 1.
c. Motor operated valve (MOV) actuator (Horcester): V1 22687, Supplement No. 9.

2.4 OTHER
a. Tank Farm Operating Procedure T0-410-950 (Draft).
b. Safety Manual, WHC-CH-1-10.
c. Building Emergency Plan, KHC-IP-0263-TF.
d. Industrial hygiene Manual, WHC-CM-1-11.
e. Tank Farm Health and Safety Plan (HASP), WHC-SD-hH-HSP-002.
f. Hanford Site Radiological Control Manual (HSRCH).
g. Environmental Compliance Manual, WHC-CH-7-5.
h. Standard Engineering Practices, WHC-CH-6-1, EP-2.2.

2.5 ENGINEERING CHANGE NOTICES (ECNS)

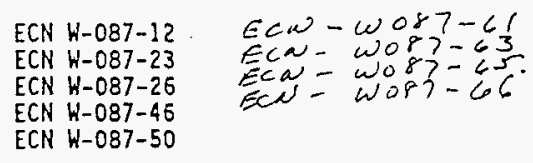


ECN W-087-54

Prior to final test approval, enter ECNS written against this ATP/OTP.

3 RESPONSIBILITIES

3.1 GENERAL

Each company or organization participating in this ATP will designate personnel to assume the responsibilities and duties as defined herein for their respective roles. The designees shall become familiar with this ATP and the systems involved to the extent that they can perform their assigned duties.

3.2 HHC PROJECT ENGINEER

3.2.1 Designates a Test Director.

3.2.2 Distributes the approved testing schedule before start of testing.

3.2.3 Schedules and conducts a pretest kickoff meeting with test participants when necessary.

3.2.4 Schedules prejob safety meetings.

3.2.5 Schedules a dry run when necessary.

3.2.6 Notifies concerned parties when a change is made in the testing. schedule.

3.2.7 Notifies the persons supporting the test 2 days before the start of testing.

3.2.8 Coordinates testing with the 219-5, 222-5, 242-5, 244-5, 200-West Area, Tank Farm Managers, Tank Farm Operations Cognizant Engineer, and Shift Hanager.

3.2.9 Acts as liaison between the participants in acceptance testing.

3.2.10 Signs Execution and Test Approval page when test is approved and accepted.

3.2.11 Takes necessary action to clear exceptions to the test.

3.2.12 Signs Exception Form when exception has been resolved.

3.2.13 Provides a distribution list for the approved and accepted ATP(ATR).

3.3 TEST DIRECTOR

3.3.1 Coordinates and directs acceptance testing.

3.3.2 Confirms that field testing and inspection of the system or portion of the system to be tested has been completed. 
3.3.3 Stops any test which, in his or her judgment, may cause damage to the system until the problem has been resolved.

3.3.4 After verifying there is no adverse impact, may alter the sequence in which systems or subsystems are tested.

3.3.5 Ensures that required environmental conditions are maintained.

3.3.6 If a test is to be suspended for a period of time, ensures that the system is left in a safe mode.

3.3.7 Before restarting suspended test, reverifies the test prerequisites.

3.3.8 Initiates ECNs to document required changes to the ATP.

3.3.9 Reviews recorded data, discrepancies, and exceptions.

3.3.10 Obtains information or changes necessary to clear or resolve objections during the performance of the test.

3.3.11 Signs Execution and Test Approval page when test has been performed.

3.3.12 Signs Exception Form when exception has been resolved.

- 3.3.13 Obtains required signatures on the ATP Master prior to reproduction and distribution.

3.4 WITNESSES (Provided by Participating Organizations. One witness shall be a Titie III acceptance inspector.)

3.4.1 Hitness the tests.

3.4.2 Review results of testing.

3.4.3 Assist the Test Director when requested.

3.4.4 Sign Execution and Test Approval page when test has been performed.

3.4.5 Sign Exception Form when exception has been resolved.

3.5 RECORDER (Provided by ICF KH)

3.5.1 Prepares a Field copy from the ATP Master.

3.5.2 Records printed names, titles, and initials of all designated personnel on Field copy of ATP prior to start of testing.

3.5.3 Records test instrument identification numbers and calibration expiration dates, as required.

3.5.4 Initiais and dates every test step on the Field copy as it is completed next to the step number or on a data sheet, when provided. Records test data. On data sheets where there is not room for both the initial and date, date may be entered at bottom of column. 
3.5.5 Records objections and exceptions on an Exception form. Uses additional Exception forms as needed. Notifies the Test Director at time the objection is made.

3.5.6 Signs Execution and Test Approval page when test has been performed.

3.5.7 After test is finished, assigns alpha numeric page numbers to added data sheets and Exception forms. Records page numbers in the Table of Contents.

3.5.8 Transfers Field copy entries for each step to the Haster in ink or type, signs, and dates. Transmits the completed Master to the Test Director for approval signature routing. Transmits the field copy to Construction Document Control for inclusion in the official project fije.

3.5.9 Signs Exception Form when exception has been resolved and transmits to Test Director.

3.6 TEST OPERATOR

3.6.1 Performs test under direction of the Test Director.

3.6.2 Provides labor, equipment, and test instruments required for performing tests which have not been designated as being provided by others.

3.6.3 Requests in writing from the Test Director those services, materials, or equipment that have been designated as being supplied by others.

3.6.4 Confirms that all equipment required for performing test will be available at the start of testing.

3.6.5 Signs the Execution and Test Approval page.

3.7 A-E ACCEPTANCE INSPECTIOH, DESIGN ENGINEER, AND PROJECT MANAGER

3.7.1 Evaluate results.

-3.7.2 Sign for A-E Approval on Execution and Test Approval page.

3.8 TANK FARM SHIFT OPERATIONS HAMAGER

3.8.1 Designates an operator to witness and/or complete the ATP/OTP for Tank Farms.

3.8.2 Assumes responsibility for the safe conduct of the ATP/OTP within Tank Farms.

3.8.3 Authorizes the start of the ATP/OTP for Tank Farms.

3.8.4 Signs Execution and Test Approval page when test is approved and accepted.

3.8.5 Signs exception form. When exception has been resolved. 
3.9 TANK FARH OPERATOR

3.9.1 Witnesses the test for Tank Farms.

3.9.2 Operates equipment as designated by the Test Director.

3.9.3 Signs Execution and Test Approval page when test has been completed.

3.9.4 Signs Exception Form when exception has been resolved.

3.10 TANK FARM COGNIZANT ENGINEER

3.10.1 Approves modifications to the ATP/OTP.

3.10.2 Signs Execution and Test Approval page when test has been completed.

3.10.3 Signs Exception Form when exception has been resolved.

3.10.4 Reviews recorded data, discrepancies, and exceptions.

4 CHANGE CONTROL

Required changes to this ATP must be processed on ECNs in accordance with company procedures. If a need for change is discovered in the course of running the test, the test director shail review the change(s) required to the procedure and discuss with the design engineer or representative. If the changes required do not affect the configuration, the changes shall be redined and signed by the design engineer and the test director for incorporation into an ECN. During this resolution, other portions of the test, unaffected by the change, may proceed.

5 EXECUTION

5.1 OCCUPATIONAL SAFETY ANC HEALTH

Individuals shall carry out their assigned work in a safe manner to protect themselves and others from undue hazards and to prevent damage to property and environment. Facility line managers shall assure the safety of activities within their areas to prevent injury, property damage, or interruption of operation. Performance of test activities shall always include safety and health aspects.

\subsection{PERFORMAITCE}

5.2.1 Conduct testing in accordance with ICF KH Procedure CON 3.5 (Performance and Recording of Acceptance Test Procedures).

5.2.2 Perform test following the steps and requirements of this procedure. 
6.1 GENERAL

Exceptions to the required test results are sequentially numbered and recorded on individual Exception forms. This enables case-by-case resolution and approval of each exception.

Errors/exceptions in the ATP itself shall NOT be processed as test exceptions (see Section 4 CHANGE CONTROL).

\subsection{RECORDING}

6.2.1 Number each exception sequentially as it occurs and record it on an Exception Form (KEH-428), sample appended.

6.2.2 Enter name and organization of objecting party for each exception.

6.2.3 Enter planned action to resolve each exception when such determination is made.

\subsection{RETEST/RESOLUTION}

Record the action taken to resoive each exception. Action taken may not be the same as planned action.

\subsubsection{When action taken results in an acceptabie retest, sign arid date Retest Execution and Acceptance section of the Exception Form.}

6.3.2 When action taken does not involve an acceptable retest, strike out the Retest Execution and Acceptance section of the Exception Form.

\subsection{APPROVAL AND ACCEPTANCE}

The customer provides final approval and acceptance of exceptions by checking one of the following on Exception Form:

6.4.1 Retest Approved and Accepted: Applicable when Retest Execution and Acceptance section is completed.

6.4.2 Exception Accepted-As-Is: Requires detailed explanation.

6.4.3 Other: Requires detailed explanation.

The customer signs and dates the Exception form and obtains other customer internal approvals, if required.

6.5 DISTRIBUTION

A copy of the approved Exception Form is distributed to each participant. The signed original is attached to the ATP Master. 
The following conditions shall exist at start of testing for that portion of the system being tested.

7.1.1 Systems have been inspected for compliance with construction documents.

7.1.2 Vendor data and operating instructions are at hand for each installed instrument, pump, and valve.

7.1.3 Reference documents (including this ATP) have been verified for correct revision number and outstanding ECNs.

7.1.4 A Job Safety Anatysis has been prepared by ICF KH and a Prejob Safety Heeting has been conducted.

7.1.5 Test instruments have a valid calibration stamp attached. Test instrument identification numbers and calibration expiration dates have been recorded in Para 7.2.

7.1.6 Methods of water disposal have been approved by Facilities Management.

7.1.8 Annunciator ijghts have bén tested.

7.1.9 Voice communications are available between 219-5, 222-5, 242-5, 244-5, leak detection sensor locations, and other locations determined to be appropriate by the test director.

7.1.10 Radiation Hork Permits (RHPs) have been approved by the Operating Contractor. Attach RHPS to ATP.

7.1.11 Pump Pl spool piece is disconnected from Tank 102.

7.1.12 Project equipment and instruments have been identified by tag numbers.

7.1.13 Shop test results for Panels IP1, IP.2, and IP3 are on file, for record, with ATP/OTP.

\subsection{EQUIPMENT/INSTRUMENTS}

Supplied by Test Operator unless otherwise noted.

7.2.1 Voltohmeters (VOM):

Instrument No. $\frac{950-45-08-0,8}{450-45-0 \%-0,5}$ Expiration Date $\frac{3-14-97}{2-26-97}$

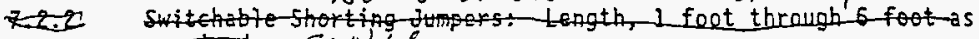
requtred. Eun 6 
7.2.3 Pressure Gages: $0-150$ psig. Pressure test assembly used for tank trailers may be used for this ATP.

7.2.4 Container: To hold water for leak detector tests, approximately 1 gallon capacity.

7.2.5 Tubing: 1/4-inch and 1/2-inch tygon.

7.3 COMPONENT LOCATION

\begin{tabular}{|c|c|}
\hline Component Identifier & Location \\
\hline Control Panel IP2 & $219-5$ \\
\hline Control Panel IP3 & $219-5$ \\
\hline $\begin{array}{l}\text { Motor Operated Valves HV-PI } \\
\text { and HV-305 }\end{array}$ & $219-5$ \\
\hline Panelboard $(219-5 X)$ & $219-5$ \\
\hline $\begin{array}{l}\text { Leak Detector Elements LDE-306A, } \\
306 \mathrm{~B}, 306 \mathrm{C}\end{array}$ & $\begin{array}{l}\text { On the transfer piping between } \\
\text { Tank-102 and } 244-5\end{array}$ \\
\hline $\begin{array}{l}\text { Leak Detector Transmitters LDT-306A, } \\
306 \mathrm{~B}, 306 \mathrm{C}\end{array}$ & $\begin{array}{l}\text { Outside, between } 219-5 \text { and } \\
244-5\end{array}$ \\
\hline Pushbuttons PEPMIT and DENY & Control Panel $A$ in $242-S$ \\
\hline
\end{tabular}

7.4 ABBREVIATIONS

$\begin{array}{ll}\text { CASS } & \text { Central Alarm Surveillance Systems } \\ \text { ECN } & \text { Engineering Change Hotice } \\ \text { LDE } & \text { Leak Detector Element } \\ \text { LOT } & \text { Leak Detector Transmitter } \\ \text { LDY } & \text { Leak Detection Relay } \\ \text { MOV } & \text { Motor-Operated Valve } \\ \text { RWP } & \text { Radiation Work Permit }\end{array}$

WHC-SU-W087-OTR-001 
This test will verify operation of the leak detection system consisting of LOE, leak detection processor, annunciation and control interlock. This system is based upon conductivity principle. When the liquid due to leak contacts both the ground probe and the leak detection probe of the LDE, leak detection relays deenergize and provide annunciation, local indication by beacon light, and interlock outputs.

\section{1}

PREPARATION

8.1 . 19156

\&6i.1

if 8415466

6.1 .2

of 815192

Ch 10li4ly 8.1 .3

if 819196

8.1.4

NOTE:

CAUTION:

Verify all prerequisites of para 7.1 and 7.2 have been met.

Notify 219-5, 222-5, 242-5, and 244-5 Building Managers. of Shift Momay rms

Notify Tank Farm Operations Manager.

Verify that energized electrical work permits have been obtained.

Keep appropriate personnel informed as to test status.

\section{AREA IS NOT HET. ENSURE THAT HANDS AND APPAREL ARE DRY.}

8.2 LEAK DETECTION AND MONITORING SYSTEM TEST

Record the following steps for each LDE/LDT loop on Data Sheet 8.2.

8.2.1 Remove LDE from pipe.

8.2.2 Apply power to monitoring units (Circuit 24,. Panelboard B at 244-5, Circuit 3 at Panelboard 242-5, and Circuits 27 at 219-5).

8.2.3 Immerse LDE in liquid. $\rightarrow 5,2,8+$ ecNis

8.2.4 Verify white indicating beacon light at 244-5 is 0ir.

8.2.5 Verify contact 1-7 of LOT in Panel IP2 at 219-S is CLOSED.

8.2.6 Verify Annunciator Window 1-1, ENCASEMENT LEAK on Panel A at 242-5 is FLASHING and audible alarm is ON.

8.2.7 Verify Annunciator Hindow 3-5, TRANSFER LINES TO 244-S on Panel IP3 at $219-5$ is FAST FLASH and audible alarm is ON.

8.2.8 Verify Group Annunciator Al-3B, Window 9, DRAIN LEAK DETECTION at 222-5 Room $3 B$ is FLASHING and audible alarm is ON.

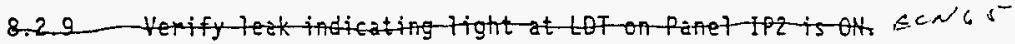

8.2.10 Verify leak indicating light at Panel IP3 is ON.

8.2.11 Depress ACKNOW'LEDE pushbutton at 219-5 and verify Annunciator Window $3-5$ is STEADY ON and audible al arm is OFF. 
8.2.12 Depress ACKNOWLEDE pushbutton at 242-S and verify Annunciator Window $1-1$ is STEADY. ON and audible alarm is OFF.

8.2.13 Depress ACKNOKLEDGE pushbutton at 222-S, Room $3 B$ and verify Annunciator Window 9 is STEADY ON and audible alarm is OFF.

8.2.14 Remove LDE from liquid and dry it off.

8.2.15 Verify white indicating beacon light at 244-S is OFF.

8.2.16 Verify leak indicating light at LDT on Panel IP2 is OFF.

8.2.17 Verify Annunciator hindow 3-5 at Panel IP3 is SLOH FLASH and audible alarm is $O N$.

8.2.18 Depress RESET pushbutton at Panel IP3 and verify Annunciator Window 3-5 and audible alarm are OFF.

8.2.19 Verify Group Annunciator Al-3B Window 9 at 222-S Room $3 B$ is OFF.

8.2.20 Verify Annunciator Window $1-1$ at $242-5$ is OFF.

8.2.21 Reinstall LDE in pipe. 


\begin{tabular}{|c|c|c|c|c|}
\hline \multicolumn{5}{|c|}{ DATA SHEET 8.2} \\
\hline \multirow{2}{*}{ STEP } & \multirow{2}{*}{ PERFORM/VERIFY } & \multicolumn{3}{|c|}{ LDE/LOT } \\
\hline & & $306 \mathrm{~A}$ & $306 \mathrm{~B}$ & $306 \mathrm{C}$ \\
\hline 8.2 .1 & Remove LDE from pipe & 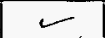 & 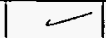 & $=$ \\
\hline 8.2 .2 & Apply power to monitoring units & 2 & 27 & - \\
\hline 8.2 .3 & Immerse LDE in liquid & $=$ & 2 & 7 \\
\hline 8.2 .4 & Verify white beacon light at $244-5$ is $\mathrm{ON}$ & $\longleftarrow$ & - & 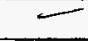 \\
\hline 8.2 .5 & $\begin{array}{l}\text { Verify Contact } 1-7 \text { of LDT at Panel IP2 is } \\
\text { CLOSED }\end{array}$ & $\sim$ & 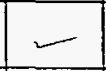 & $\leftarrow$ \\
\hline 8.2 .6 & $\begin{array}{l}\text { Verify } 242-S \text { Annunciator Hindow } 1-1 \text { is } \\
\text { FLASHING and audible alarm is ON }\end{array}$ & 2 & 2 & 2 \\
\hline 8.2 .7 & $\begin{array}{l}\text { Verify } 219-5 \text { Annunciator Window 3-5 is FAST } \\
\text { FLASH and audible alarm is ON }\end{array}$ & - & - & - \\
\hline 8.2 .8 & $\begin{array}{l}\text { Verify 222-S Group Annunciator Window } 9 \text { is } \\
\text { FLASHING and audible alarm is ON }\end{array}$ & $\leftarrow$ & $\sim$ & - \\
\hline 8.2 .9 & $\begin{array}{l}\text { Verify teak-indicating light at tol-oA } \\
\text { Ranel IP2 is oH Delete ECNLS }\end{array}$ & 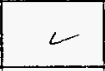 & - & - \\
\hline 8.2 .10 & $\begin{array}{l}\text { Verify leak indicating light at Panel IP3 is } \\
\text { ON }\end{array}$ & ᄃ & 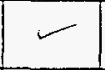 & - \\
\hline 8.2 .11 & $\begin{array}{l}\text { Depress ACKNOWLEDGE pushbutton at } 219-5 \text { and } \\
\text { verify Annunciator Window } 3-5 \text { is ON and } \\
\text { audible alarm is OFF }\end{array}$ & $\longleftarrow$ & 2 & \\
\hline 8.2 .12 & $\begin{array}{l}\text { Depress ACKROWLEDGE pushbutton at } 242-S \text { and } \\
\text { verify Annunciator Window 1-1 is STEAOY ON and } \\
\text { audible alarm is OFF }\end{array}$ & $c$ & - & - \\
\hline 8.2 .13 & $\begin{array}{l}\text { Depress ACKNOHLEDGE pushbutton at } 222-5 \\
\text { Room } 33 \text { and verify Annunciator window } 9 \text { is } \\
\text { STEADY ON and audible alarm is OFF. }\end{array}$ & $\sim$ & & - \\
\hline 8.2 .14 & Remove LDE from liquid and ory it off & - & - & - \\
\hline 8.2 .15 & Verify white beacon light at $244-5$ is off & $\simeq$ & $=$ & - \\
\hline 8.2 .16 & $\begin{array}{l}\text { Yerify leak indicating light at LDT on Panel } \\
\text { IP2 is OFf }\end{array}$ & - & & \\
\hline 8.2 .17 & $\begin{array}{l}\text { Verify Annunciator lindow } 3-5 \text { at Panel IP3 is } \\
\text { SLOW FLASH and audible alerm is ON }\end{array}$ & & & - \\
\hline 8.2 .18 & $\begin{array}{l}\text { Depress RESET pushbutton at Panel IP3 and } \\
\text { verify Annunciator Hindow 3-5 and audible } \\
\text { alarm are OFF }\end{array}$ & $\sigma$ & & 2 \\
\hline 8.2 .19 & $\begin{array}{l}\text { Verify Group Annunciator Window } 9 \text { at } 222-S \\
\text { Room } 33 \text { is OFF }\end{array}$ & $r$ & - & - \\
\hline 8.2 .20 & Verify Annunciator Kindow $1-1$ at $242-5$ is OFF & 5 & 2 & $\leftarrow$ \\
\hline 8.2 .21 & Reinstall LDE in pipe & $C^{3 / 4}$ & Chy & 258 \\
\hline \multirow{2}{*}{\multicolumn{2}{|c|}{$\begin{array}{l}8,2.20 \text { a-Deenergize Circuit } 24 a 2445 \\
8.2 .21 \text { a -Evergize Circuit 24 END OF SECTION } 8\end{array}$}} & a & C & 9 \\
\hline & & $\mathscr{U}$ & 8 & $a_{1}$ \\
\hline
\end{tabular}


This test will verify speed control operation of Pump P-1 in 219-S.

\subsection{PREPARATION}

Ch/c/ll/gl 9.1.1 Verify all prerequisites of Para 7.1 and 7.2 have been met.

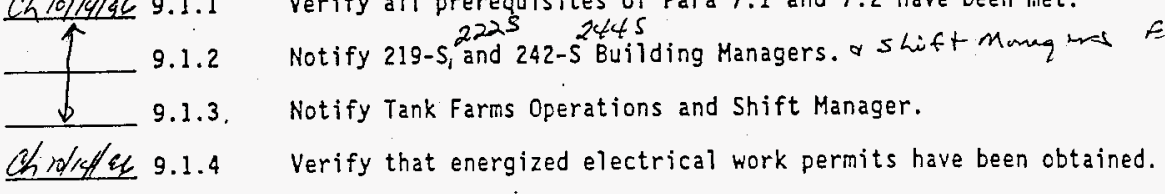

NOTE: Keep appropriate personnel informed as to test status.

CAUTION: TEST INVOLYES KORKING WITH LIVE CIRCUITS. ENSURE THAT THE IMMEDIATE AREA IS NOT WET. ENSURE THAT HANDS AND APPAREL RRE DRY.

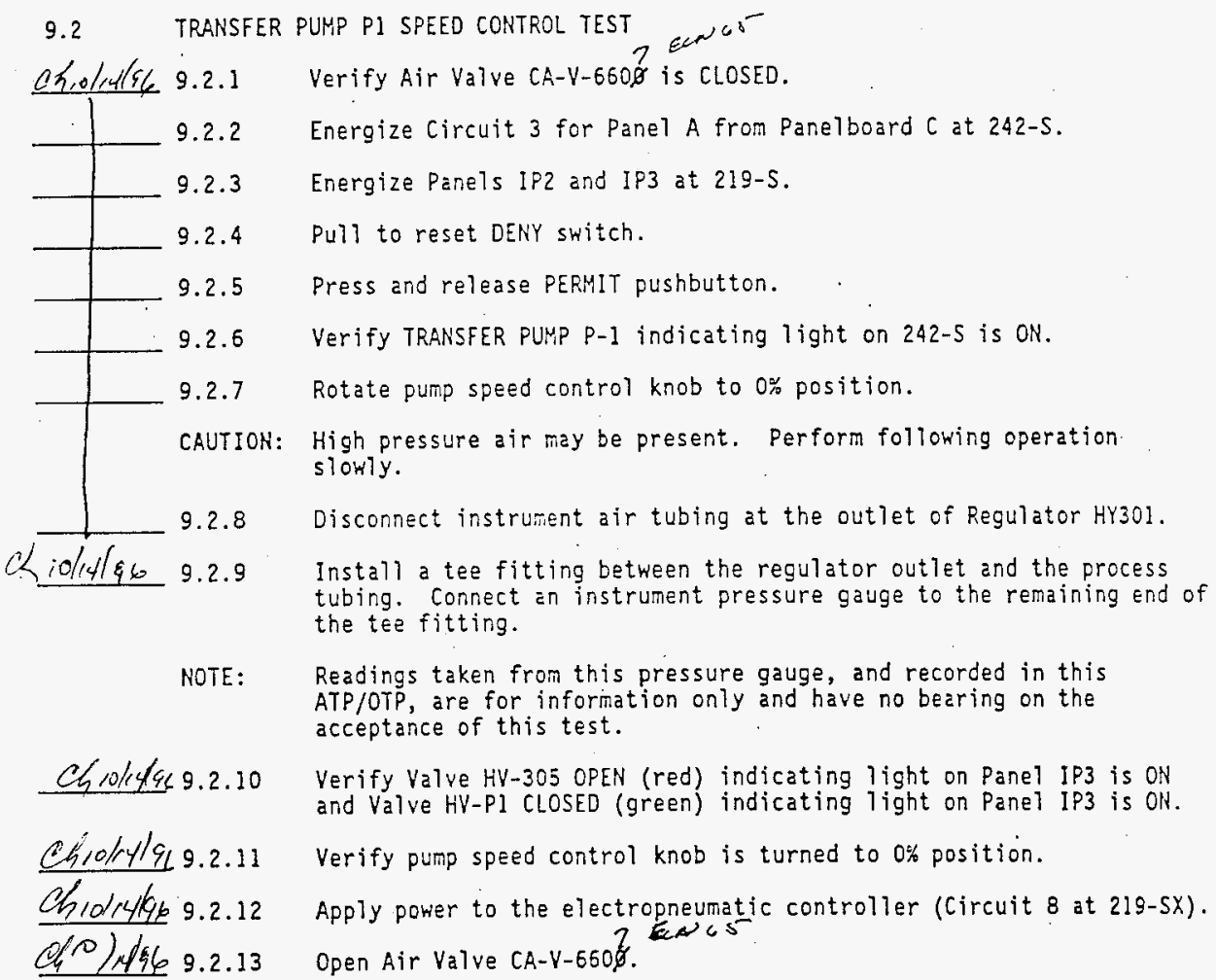

HNF-SD-W087-0TR-001 


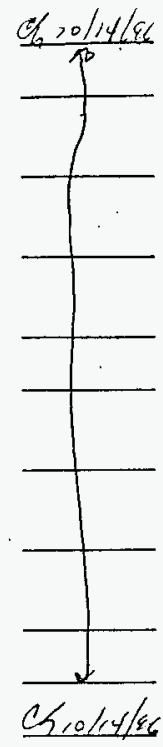

9.2.14 Record reading on the pressure gauge.

Q psi

9.2.15 Turn Hand Switch HS-305 to CLOSE position and hold while verifying the following.

9.2.15.1 As the valve travels toward the closed position, verify both OPEN (red) and CLOSED (green) indicating lights are ON.

9.2.15.2 When the valve reaches the fully closed position, verify OPEN indicating light is OFF and CLOSED indicating light is ON.

9.2.16-Release Hent Sitch-HS-305 to Atoposition. ECNC5

9.2.17 Turn Hand Switch HS-Pl to OPEN position and hold while verifying the following.

9.2.17.1 As the valve travels toward the open position, verify both OPEN (red) and CLOSED (green) indicating lights are ON.

9.2.17.2 When the valve reaches the fully open position, verify CLOSED indicating light is OFF and OPEN indicating light is ON.

9.2.18 Release Hand Switch HS-P1 to AUTO position.

9.2.19 Slowly rotate pump speed control knob clockwise to $50 \%$ position.

9.2.20. Record reading on the pressure gauge. 20 psi

NOTE: This reading should be higher than that taken with pump speed control knob at $0 \%$.

Chiolruls6 9.2.21 Slowly rotate pump speed control knob to $100 \%$ position.

Chloleflet 9.2.22 Record reading on the pressure gauge. 22 psi

NOTE: This reading should be higher than that taken with pump speed control knob at $50 \%$.

Chro/rtal 9.2.23

CK10/4/5ib

9.2 .24

NOTE:

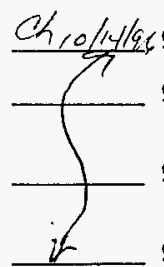

Chiolutas
Slowly rotate pump speed control knob back to $0 \%$ position.

Record reading on the pressure gauge.

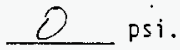

This reading should be approximately the same as that taken when pump speed control knob was first at $0 \%$ position.

Turn Hand Switch HS-P1 to CLOSE position and verify the following.

9.2.25.1 As the valve traveis toward the closed position, verify both OPEN and CLOSED indicating lights are ON.

9.2.25.2 When the valve reaches the fully closed position, verify CLOSED indicating light is ON and OPEN indicating light is OFF.

9.2.25.3 Verify the closing of Vaive HV-Pl has caused Valve HV-305 to OPEN. 9.2.26 Close Air Valve CA-V-660\%. 
CAUTION: HIGH PRESSURE AIR MAY BE PRESENT. PERFORM FOLLOHING OPERATION SLOKLY.

Chol/1/969.2.28 Remove power from Regulator HY301.

9.2.27 Reconnect the tubing to outlet side of Regurator Hr3015 ECN E

END OF SECTION 9 
These tests will verify that Hotor Operated Valves HV-Pl and HV-305 operate in accordance with their respective elementary (control) diagram requirements.

HV-Pl is controlled by a 3 position (OPEN-AUTO-CLOSE) control switch which can be maintajned in either AUTO or CLOSE position but will spring-return from OPEN to AUTO.

HV-305 is controlled by a 3 position (CLOSE-AUTO-OPEN) control switch which can be maintained in either AUTO or OPEN position but will spring-return from CLOSE to AUTO.

Operation of HV-PI is dependent on the operation of HV-305. HV-PI is designed as automatic CLOSE and manual override CLOSE while HV-305 is designed as automatic OPEN and manual override OPEN. In other words, HV-PI will not OPEN unless HV-305 is CLOSED.

\subsection{PREPARATION}

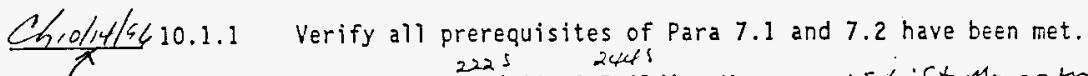

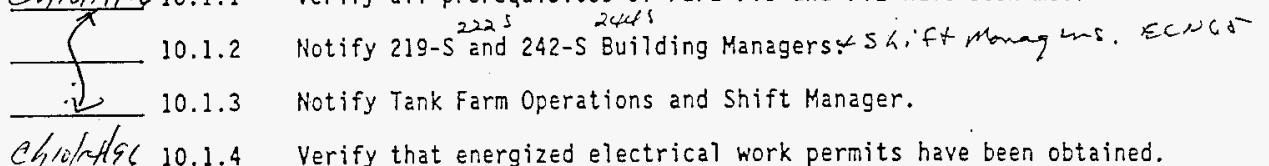

NOTE: Keep appropriate personnel informed as to test status.

CAUTION: TEST INVOLVES WORKING HITH LIVE CIRCUITS. ENSURE THAT THE IMMEDIATE AREA IS NOT HET. ENSURE THAT HANDS AND APPAREL ARE DRY.

10.2 MOTOR OPERATED VALVE HV-PI AND HV-305 TEST

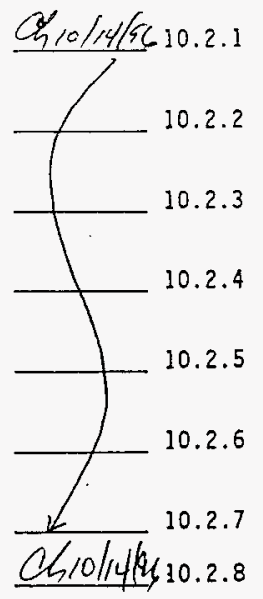

Place Circuit Breaker 7 in Panelboard 219-SX, at Building 219-5, in the OFF position.

Verify there is NO VOLTAGE across Terminals TB2-205 and TB2-206 at Panel IP3.

Place Circuit Breaker 7 in Panelboard 219-SX, at Building 219-5, in the on position.

Place Circuit Breaker 27 in Panelboard 219-5, at Building 219-5, in the of position.

Place Circuit No. 3 in Panelboard C, at Building 242-S, in the $O N$ position.

Verify DENY pushbutton in Panel A, at Building 242-S, is in PULL TO RESET position.

Press and release PERMIT pushbutton in Panel $A$ at Building 242-5. Using VOM verify $120 \mathrm{~V}$ ac across Terminals TB2-201 and TB1-7N2. 
(//2/4/46 10.2.9 Verify PERMITTED indicating light on Panel IP3 is ON.

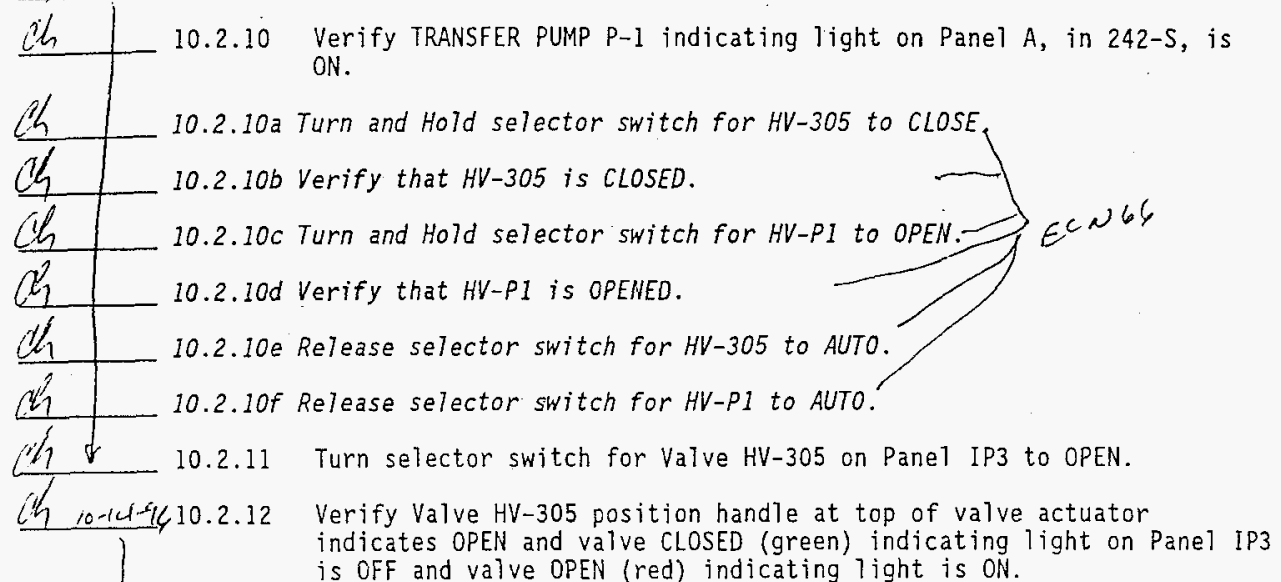
indicates OPEN and valve CLOSED (green) indicating light on Panel IP3 is OFF and valve OPEN (red) indicating light is ON.

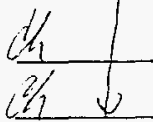

10.2.12a Verify that HV-P1 closes. ECN L6

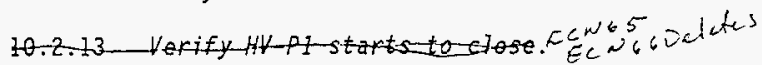

$1 / 2,0+4.4 \mathrm{CI}$

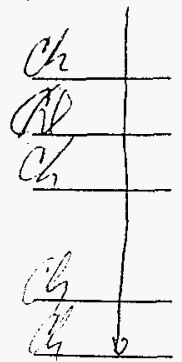

10.2 .15

10.2 .16

10.2 .17

10.2 .18

10.2 .19

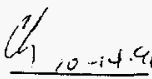

4610.2 .20

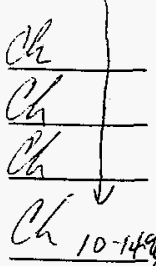

10.2 .21

10.2 .22

10.2 .23

$10-149810.22 .24$
Verify valve HV-Pl position handle at top of valve actuator indicates CLOSE and valve CLOSED indicating light on Panel IP3 is ON.

Using VOM verify Relay $K-V$ on Panel IP2 is ENERGIZEO.

Turn selector switch for HV-P1 from CLOSE to AUTO.

Verify Valve HV-Pl position handle at top of valve actuator continues to indicate CLOSE and valve CLOSED indicating light on Panel IP3 remains $O N$.

Turn and hold selector switch for HV-PI in OPEN position.

As Valve HV-Pl travels toward the open position, verify both OPEN and CLOSED indicating lights are $O N$.

When Valve HV-Pl reaches the fully open position, verify CLOSED indicating light is OFF and OPEN indicating light is ON.

Release selector switch for HV-PI to AUTO.

Verify Valve HV-Pl begins to close.

As Valve HV-Pl travels toward the closed position, verify both OPEN and CLOSED indicating lights are $O N$.

When Valve HV-Pl reaches the fully closed position, verify OPEN indicating light is OFF and CLOSED indicating light is ON. 
$C / 214 C_{10} 10.2 .25$

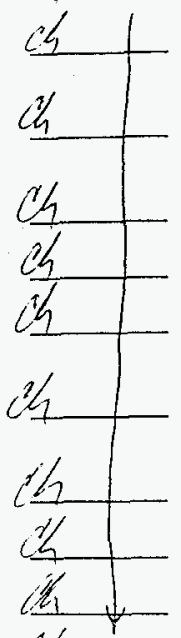

10.2 .25

10.2 .27

10.2 .28

10.2 .29

10.2 .30

10.2 .31

$10.2 .31 a$

10.2 .32

10.2 .33

ch juctel10.2.34

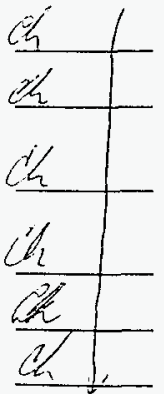

10.2 .35

10.2 .36

10.2 .37

$10.2 .37 a$

$10.2 .37 b$

10.2 .38

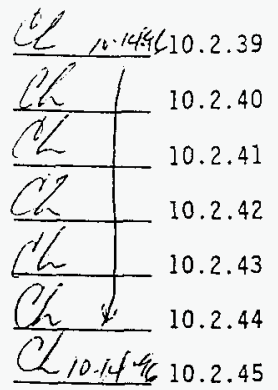

Turn and hold selector switch for HV-305 in CLOSE position.

As Valve HV-305 travels toward the closed position, verify both OPEN and CLOSED indicating lights are ON.

When valve position handle on Valve HV-305 shows fully closed, verify CLOSED indicating light is ON and OPEN indicating light is OFF.

\section{Deleted ENCa-}

Turn and hold selector switch for HV-Pl in OPEN position.

As Valve HV-Pl travels toward the open position, verify both OPEN and CLOSED indicating lights are ON.

When valve position handle on Valve HV-Pl shows fully open, verify OPEN indicating light is ON and CLOSED indicating light is OFF.

Release selector switch for HV-305 to AUTO. ECNGS

Release selector switch for HV-P1 to AUTO position.

Turn selector switch for HV-305 to OPEN position.

Verify Valve HV-305 starts to OPEN.

Verify HV-PI begins to CLOSE as soon as HV-305 is fully OPEN.

Turn and hold selector switch for HV-305 in CLOSE position until HV-305 is CLOSED and Step 10.2.37 is complete. EC+J 65

Turn and hold selector switch for HV-PI in OPEN position until HV-PI is OPEN.

Release selector switch for HV-305 to AUTO.

Release selector sivitch for HV-PI to AUTO.

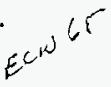

Depress DENY switch to Push to Deny position on Panel A in 242-S Control Room.

Verify PERMITTED indicating light on Panel IP3 is OFF.

Verify TRANSFER PUMP $P-1$ indicating light on Panel $A$ in 242-S is OFF.

Pull DENY switch to PulT to Reset position on Panel A in 242-5.

Verify HV-Pl begins to CLOSE. ECNC:

Verify HV-305 begins to OPEN. ECN 65

Using VOM verify Relay K-P on Panel IP2 is ENERGIZED.

Verify HV-305 position handle at top of valve actuator is in OPEN position.

$$
\begin{aligned}
& \text { END OF SECTION } 10 \\
& \qquad \begin{aligned}
&-21- \text { HNF-SD-W087-0TR-001 } \\
& \text { Rev. } 1 \\
& 4 / 28 / 97
\end{aligned}
\end{aligned}
$$


11 INTEGRATED SYSTEM (DRY) TEST AND INTERLOCK VERIFICATION

This test will demonstrate overall system operation by verifying the various interlocks perform the design functions. During this test no liquid will be pumped out of the tanks. Pump vendor assures that the pump can be run "DRY" for certain time duration.

\subsection{PREPARATION}

Chollefis 11.1.1 Verify all prerequisites of Para 7.1 and 7.2 have been met.

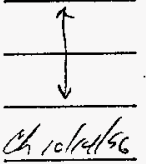

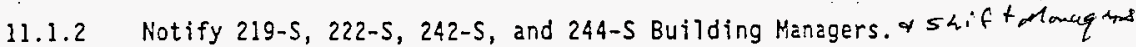

11.1:3 Notify Tank Farm Operations and Shift Manager.

11.1.4 Verify that energized electrical work permits have been obtained.

NOTE: Keep appropriate personnel informed as to test status.

Cholf/gC 11.1.5 Verify all previous ATP sections have been completed satisfactorily.

11.2 SYSTEM TEST

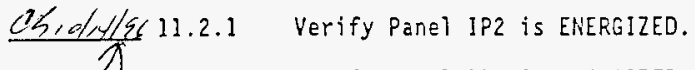

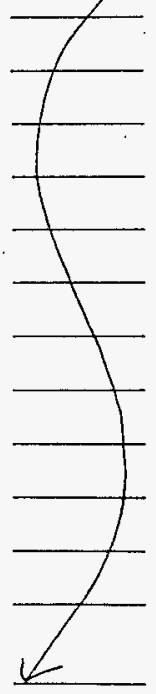

11.2.2 Verify Panel IP3 is ENERGIZEO.

11.2.3 Verify Parel $A$ in 242-S is ENERGJZEQ.

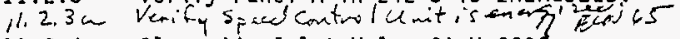

11.2.4 Close Air Inlet Valve CA-V-660ฏ.

11.2.5 Verify DENY switch in Panel A at 242-S is in Pull to Reset position.

11.2.6 Press and release PEPMIT pushbutton in Panel A at 242-S.

11.2.7. Verify TRAHSFER PUHP P-1 indicating light at Panel A 242-S is ON.

11.2.8 Verify PEPMITTED indicating light on Panel IP3 is OH.

11.2.9 Verify siphon Valve HV-305 is OPEN.

H.z.10 Verify teak detection indicating light-on Panel-IPz-is QFF, ECN $\mathrm{CS}^{-}$

11.2.11 Verify leak detection indicating light on Panel IP3 is OFF.

11.2.12 Verify pump diaphragm leak indicating light on Panel IP3 is OFF.

11.2.13 Verify Pump Pl (air inlet) hand switch on Panel IP3 is in CLOSE position.

11.2.14 Turn HV-PI hand switch to OPEN and hold it momentarily in that position.

10/14/96 11.2.15" Verify HV-P1 begins to OPEN as indicated by both RED and GREEN indicating lights $\mathrm{ON}$. 
Verify HV-P1-begins to OPEN as indiEated-by-both REQ and-GREEN indicating lights ofr. Deplicutiven

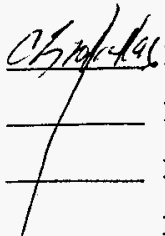

Release HV-P1 hand switch allowing it to return to AUTO.

11.2.17 Verify HV-P1 begins to Close.

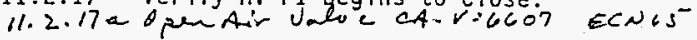

11.2.18 Turn and Hold selector switch for Siphon Valve HV-305 to CLOSE.

11.2.19 Deleted

11.2.20 Verify HV-305 is CLOSE as indicated by indicating.light.

11.2.21 Deleted

11.2.22 Turn and hold HV-Pl hand switch on Panel IP3 to OPEN.

11.2 .23 Deleted

11.2.23a Release selector switch for HV-305 to AUTO.

11.2.24 Release HV-Pl hand switch to AUTO.

$11.2 .24 a$ Open Air Valve CA-V-6607.

11.2.24b Rotate speed control knob until it reads approximately 10 psig on pressure gauge.

11.2.25. Verify Pump P1 continues to run as indicated by indicating OPEN light.

11.2.26 Lift wire marked LD-306A-4 at terminal 7 at panel IP2.

11.2.27 Verify valve HV-PI starts to CLOSE.

11.2.28 Verify siphon Valve HV-305 starts to OPEN.

11.2.28a Observe LEAK DETECTED indicating light is illuminated, TRANSFER LINE TO 244-S LEAK annunciator FAST FLASH and audible ON.

11.2.28b Acknowledge annunciator.

11.2.29 Reconnect wire at terminal 7 at panel IP2.

11.2.30 Verify Pump P1 remains STOPPED.

11.2.31 Turn and Hold selector switch for HV-305 to CLOSE.

11.2.32 Turn and Hold selector switch for HV-PI to OPEN.

11.2.33 Verify Pump P1 STARTS.

11.2.33a Release selector switch for HV-305 to AUTO.

11.2.34 Release selector switch for HV-PI to AUTO. 


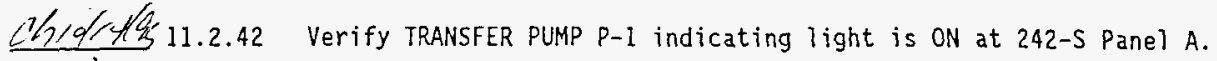

11.2.43 Verify PERMITTED indicating light on Panel IP3 is ON.

$11.2 .43 a$ Turn and hold selector switch for HV-305 in the close position.

$11.2 .43 b$ Verify that HV-305 is CLOSED.

11.2.43C Turn and hold selector switch for HV-PI in the OPEN position.

11.2.44 Verify pump Pl starts.

11.2 .44 a Release selector switch for HV-305.

11.2.44b Release selector switch HV-PI.

11.2.45 Simulate a leak in the P1 diaphragm at LDY-PI by disconnecting power at TB1-8H1.

11.2.45a Verify DIAPH LEAK indicating light at IP3 is illuminated.

11.2.45b Verify TANK 102 PUmP PI DIAPH LEAK annunciator window FAST FLASH and audible $O N$.

11.2.45c Acknowledge annunciator. Verify annunciator window STEADY ON and audible OFF.

11.2.46 Verify Pump Pl air inlet valve starts to CLOSE.

11.2.47 Verify valve HV-305 opens.

11.2.48 Return LOY-PI to the Normal Mode by reconnecting power at TB1-8HI.

11.2.48a Verify DIAPH LEAK indicating light is not jlluminated.

11.2.48b Verify TANK 102 PUMP P1 DIAPH LEAK annunciator window SLOW FLASH and audible ON.

11.2.48c Reset annunciator.

11.2.49 Close air valve CA-V-6600.

11.2.50 Return system to normal and safe configuration.

END OF SECTION 11 


\section{APPENDIX A}

\section{Retest of leak detection}

Explanation of Appendix A: Surveillance ISR 2W-96-12 identified some wiring for the leak detection system that had the wrong colored insulation. This wiring was changed. In this appendix is the retest of the leak detection system. Only Sections 1 thru 8 were performed. Sections 9 thru 11 were unaffected by the surveillance. The testing was successful and the leak detection system is operational. 
EXEECUTION AND TEST APPROVAL
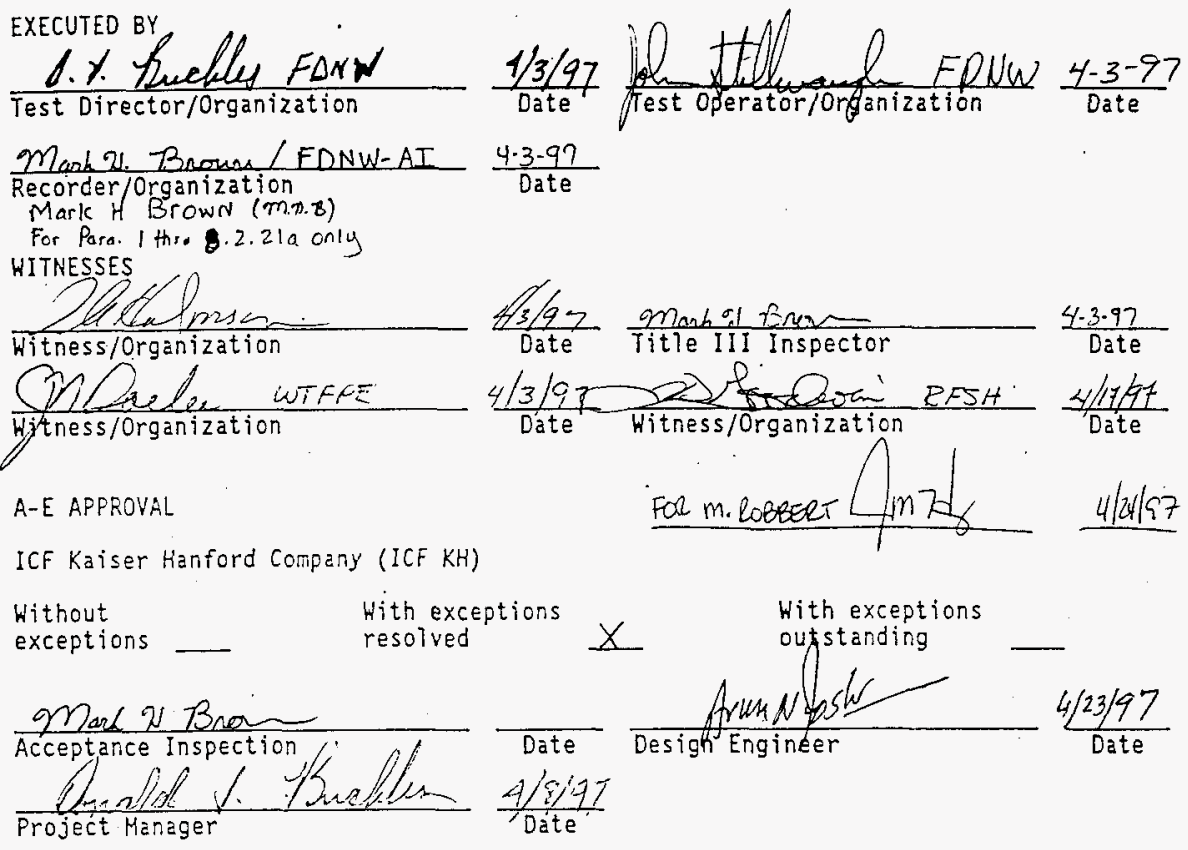

TEST APPROVAL AND ACCEPTANCE

Hestinghouse Hanford Company (HHC)

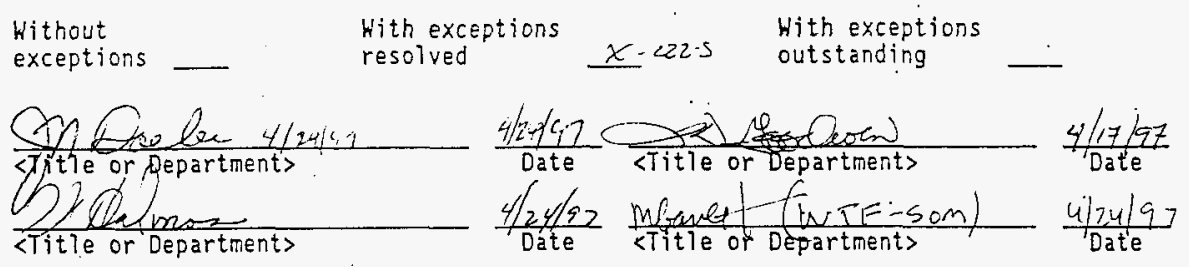




\section{Appendix A}

\section{TABLE OF CONTENTS}

Section

TITLE/PROCEDURE APPROVAL

Page

EXECUTION AND TEST APPROVAL

TABLE OF CONTENTS

A-2

PURPOSE

A-3

1

REFERENCES

A-4

2

RESPONSIBILITIES

A-5

3

CHANGE CONTROL

A-6

4

5

EXECUTION

A-9

A-9

6

EXCEPTIONS

A-10

7 PREREQUISITES, EQUIPMENT/INSTRUMENTS, COMPONENT LOCATIONS, AND ABBREVIATIONS

8 LEAK DETECTION AND HONITORING SYSTEM

A-13

9

TRANSFER PUMP PI SPEED CONTROL

A-16

10

MOTOR OPERATED VALVES HV-PI AND HV-305

A-19

11

INTEGRATED SYSTEM (DRY) TEST AND INTERLOCK VERIFICATION

A-22

EXCEPTION FORM

$A-25$

NOTE: At completion of test, enter pages added during performance of test. to this Table of Contents. 


\section{Appendix A}

PURPOSE

This Acceptance Test Procedure/Operational Test Procedure (ATP/OTP) has been prepared to demonstrate that the Electrical/Instrumentation and Hechanical systems function as required by project criteria and to verify proper operation of the integrated system including the interlocks.

The equipment to be tested includes the following:

a. Leak detection system operation and controls.

b. Electrical interlocks.

c. Transfer pump operation.

d. Vacuum breaker system interlocks.

The following tests will ensure the operation of the equipment used in support of radioactive liquid transfer from 222-S Laboratory Facility to 219-5, 242-5, and then to 244-S. This test will include checks on associated annunciator systems.

The leak detection system uses 3 leak detector elements (LDEs) to monitor the entire length of pipe installed between 219-5 and 244-5.

a. LDE-306A monitors approximately 925 feet of pipe between $219-5$ and LDE-306A.

b. LDE-3063 monitors approximately 1000 feet of pipe between LDE-306A and LDE-306B.

c. LDE $306 C$ monitors approximately 1005 feet of pipe between $L D E-306 B$ and LDE-306C.

The leak detectors are connected to leak detection panels mounted locally. The signals are transmitted to control panels located at 219-5, 242-5 and 244-S. Leak detection annunciation is provided at $219-S, 222-5$ Room $3 B, 242-5$ and 244-S; and has capability to connect to Central Alarm Surveillance System (CASS).

The leak detection signals are connected to the transfer pump interlock. The pump interlocks are arranged such that evidence of leak in any section of the pipe, or a pump diaphragm leak, or a manual override by the DENY pushbutton will stop pump operation.

The transfer pump is air operated diaphragm type, operated by pneumatic controller. Air supply to the pump is controlied by an in line motor operated valve. If leak detection system is activated, the pump interlock circuit will prevent pump operation. In addition, if pump diaphragm should leak, pump interlock circuit will prevent pump operation. 


\section{Appendix A}

2 REFERENCES

2.1 DRAWINGS

2.1.1 Project $W-087$ Drawings

H-2-820841, Sh 1 and 2, Rev 0 H-2-820842, Sh 1, Rev. O $\mathrm{H}-2-820843$, Sh 1, Rev. 0 $\mathrm{H}-2-820848$ Sh 1, Rev 0

Instrumentation Conn. Diagrams

242-S Panel A Modifications

242-S Panel A Interconn. Diagram

Leak Detection, Elem. Diagran

2.1.2 Project $W-178$ Drawings Showing Interface with Project $W-087$

H-2-825536, Sh 1, Rev. 0 H-2-825549' Sh 1, Rev 0 H-2-825550 Sh 1, Rev O
Cell A \& Operating Gallery

Leak Detection Panel IP2

Control Panel IP3

\subsection{SPECIFICATIONS}

$\begin{array}{ll}\text { W-087-C1, Rev } 0 & \text { Construction Specification } \\ \text { W-087-C2, Rev } 0 & \text { Construction Specification }\end{array}$

2.3 VENDOR INFORMATIOH
a. Leak detection system (B/W Magnatek): VI 22687, Supplement No. 8.
b. Diaphragm pump and diaphragm leak detection and speed control unit (Sandpiper): VI 22687, Supplement No. 1.
c.
Motor operated valve (MOV) actuator (horcester): VI 22687 , Supplement No. 9.

2.4 OTHER
a.
Tank Farm Operating Procedure T0-410-950 (Draft).
b.
Safety Menual, $\mathrm{KHC}-\mathrm{CH}-1-10$.
c. Building Emergency Plan, HHC-IP-0263-TF.
d. Industrial Hygiene Hanual, WHC-CH-1-11.
e. Tank Farm Health and Safety Plan (HASP), WHC-SD-WH-HSP-002.
f. Hanford Site Radiological Control Manual (HSRCH).
g. Environmental Compliance Manual, WHC-CM-7-5.
h. Standard Engineering Practices, WHC-CM-6-1, EP-2.2.

2.5 ENGINEERING CHANGE NOTICES (ECNS)
ECN $W-087-12$
ECN-W087-61
ECN $\mathrm{H}-087-23$
$E C N-\omega 087-63$
ECN H-087-26
ECN $W-087-46$
ECN $W-087-50$
$E C N-\omega 087-65$
$E C N-\omega 087-66$ 


\section{Appendix A}

ECN $\mathrm{H}-087-54$

Prior to final test approval, enter ECNs written against this ATP/OTP.

3 RESPONSIBILITIES

3.1 GENERAL

Each company or organization participating in this ATP will designate personnel to assume the responsibilities and duties as defined herein for their respective roles. The designees shall become familiar with this ATP and the systems involved to the extent that they can perform their assigned duties.

3.2 WHC PROJECT ENGINEER

3.2.1 Designates a Test Director.

3.2.2 Distributes the approved testing schedule before start of testing.

3.2.3 Schedules and conducts a pretest kickoff meeting with test participants when necessary.

3.2.4 Schedules prejob safety meetings.

3.2.5 Schedules a dry run when necessary.

3.2.6 Notifies concerned parties when a change is made in the testing schedule.

3.2.7 Notifies the persons supporting the test 2 days before the start of testing.

3.2.8 Coordinates testing with the 219-5, 222-5, 242-5, 244-5, 200-hest Area, Tank Farm Hanagers, Tank Farm Operations Cognizant Engineer, and Shift Manager.

3.2.9 Acts as liaison bstween the participants in acceptence testing.

3.2.10 Signs Execution end Test Approval page when test is approved and accepted.

3.2.11 Takes necessary action to clear exceptions to the test.

3.2.12 Signs Exception form when exception has been resolved.

3.2.13 Provides a distribution list for the approved and accepted ATP(ATR).

3.3 TEST DIRECTOR

3.3.1 Coordinates and directs acceptance testing.

3.3.2 Confirms that field testing and inspection of the system or portion of the system to be tested has been completed. 


\section{Appendix A}

3.3.3 Stops any test which, in his or her judgment, may cause damage to the system until the problem has been resolved.

3.3.4 After verifying there is no adverse impact, may alter the sequence in which systems or subsystems are tested.

3.3.5 Ensures that required environmental conditions are maintained.

3.3.6 If a test is to be suspended for a period of time, ensures that the system is left in a safe mode.

3.3.7 Before restarting suspended test, reverifies the test prerequisites.

3.3.8 Initiates ECNs to document required changes to the ATP.

3.3.9 Reviews recorded data, discrepancies, and exceptions.

3.3.10 Obtains information or changes necessary to clear or resolve objections during the performance of the test.

3.3.11 Signs Execution and Test Approval page when test has been performed.

3.3.12 Signs Exception Form when exception has been resolved.

- 3.3.13 Obtains required signatures on the ATP Master prior to reproduction and distribution.

3.4 WITNESSES (Provided by Participating Organizations. One witness shall be a Title III acceptance inspector.)

3.4.1 Witness the tests.

3.4.2 Review results of testing.

3.4.3 Assist the Test Director when requested.

3.4.4 Sign Execution and Test Approval page when test has been performed.

3.4.5 Sign Exception Form when exception has been resolved.

3.5 RECORDER (Provided by ICF KH)

3.5.1 Prepares a Field copy from the ATP Master.

3.5.2 Records printed names, titles, and initials of all designated personnel on Field copy of ATP prior to start of testing.

3.5.3 Records test instrument identification numbers and calibration expiration dates, as required.

3.5.4 Initials and dates every test step on the Field copy as it is completed next to the step number or on a data sheet, when provided. Records test data. On data sheets where there is not room for both the initial and date, date may be entered at bottom of column. 


\section{Appendix A}

3.5.5 Records objections and exceptions on an Exception form. Uses additional Exception forms as needed. Notifies the Test Director at time the objection is made.

3.5.6 Signs Execution and Test Approval page when test has been performed.

3.5.7 After test is finished, assigns alpha numeric page numbers to added data sheets and Exception forms. Records page numbers in the Table of Contents.

3.5.8 Transfers Field copy entries for each step to the Master in ink or type, signs, and dates. Transmits the completed Master to the Test Director for approval signature routing. Transmits the Field copy to Construction Document Control for inclusion in the official project file.

3.5.9 Signs Exception Form when exception has been resolved and transmits to Test Director.

\subsection{TEST OPERATOR}

3.6.1 Performs test under direction of the Test Director.

3.6.2 Provides labor, equipment, and test instruments required for performing tests which have not been designated as being provided by others.

3.6.3 Requests in writing from the Test Director those services, materials, or equipment that have teen designated as being supplied by others.

3.6.4 Confirms that all equipment required for performing test will be available at the start of testing.

3.6.5 Signs the Execution and Test Approval page.

3.7 A-E ACCEPTANCE INSPECTION, DESIGN ENGINEER, AND PROJECT HAMAGER

3.7.1 Evaluate results.

-3.7.2 Sign for A-E Approval on Execution and Test Approval page.

3.8. TANK FARM SHIFT OPERATIONS HANAGER

3.8.1 Designates an operator to witness and/or complete the ATP/OTP for Tank Farms.

3.8.2 Assumes responsibility for the safe conduct of the ATP/OTP within Tank Farms.

3.8.3 Authorizes the start of the ATP/OTP for Tank Farms.

3.8.4 Signs Execution and Test Approval page when test is approved and accepted.

3.8.5 Signs exception Form. when exception has been resolved. 


\section{Appendix A}

3.9 TANK FARM OPERATOR

3.9.1 Witnesses the test for Tank Farms.

3.9.2 Operates equipment as designated by the Test Director.

3.9.3 Signs Execution and Test Approval page when test has been completed.

3.9.4 Signs Exception Form when exception has been resolved.

3.10 TANK FARM COGNIZANT ENGINEER

3.10.1 Approves modifications to the ATP/OTP.

3.10.2 Signs Execution and Test Approval page when test has been completed.

3.10.3 Signs Exception Form when exception has been resolved.

3.10.4 Reviews recorded data, discrepancies, and exceptions.

4 CHANGE CONTROL

Required changes to this ATP must be processed on ECHs in accordance with company procedures. If a need for change is discovered in the course of running the test, the test director shail review the change(s) required to the procedure and discuss with the design engineer or representative. If the changes required do not affect the configuration, the changes shall be redlined and signed by the design engineer and the test director for incorporation into an ECN. During this resolution, other portions of the test, unaffected by the change, may proceed.

5 EXECUTION

5.1 OCCUPATIONAL SAFETY ANE HEALTH

Individuais shall carry out their assigned work in a safe menner to protect themselves and others from undue hazaro's and to prevent damage to property and environment. Facility line managers shall assure the safety of activities within their areas to prevent injury, property damage, or interruption of operation. Performance of test activities shall always include safety and health aspects.

\subsection{PERFORMANCE}

5.2.1 Conduct testing in accordance with ICF KH Procedure CON 3.5 (Performance and Recording of Acceptance Test Procedures).

5.2.2 Perform test following the steps and requirements of this procedure. 


\section{Appendix A}

6 EXCEPTIONS

6.1 GENERAL

Exceptions to the required test results are sequentially numbered and recorded on individual Exception forms. This enabies case-by-case resolution and approval of each exception.

Errors/exceptions in the ATP itself shall NOT be processed as test exceptions (see Section 4 CHANGE CONTROL).

6.2 RECORDING

6.2.1 Number each exception sequentially as it occurs and record it on an Exception Form (KEH-428), sample appended.

6.2.2 Enter name and organization of objecting party for each exception.

6.2.3 Enter planned action to resolve each exception when such determination is made.

6.3 RETEST/RESOLUTION

Record the action taken to resolve each exception. Action taken may not be the same as planned action.

6.3.1 When action taken results in an acceptable retest, sign and date Retest Execution and Acceptance section of the Exception Form.

6.3.2 When action taken does not involve an acceptable retest, strike out the Retest Execution and Acceptance section of the Exception Form.

\subsection{APPROVAL AND ACCEPTANCE}

The customer provides final epproval and acceptance of exceptions by checking. one of the following on Exception Form:

6.4.1 Retest Approved and Accepted: Applicable when Retest Execution and Acceptance section is completed.

6.4.2 Exception Accepted-As-Is: Requires detailed explanation.

6.4.3 Other: Requires detailed explanation.

The customer signs and dates the Exception form and obtains other customer internal approvals, if required.

6.5 DISTRIBUTION

A copy of the approved Exception form is distributed to each participant. The signed original is attached to the ATP Master. 


\section{Appendix A}

PREREQUISITES, EQUIPMENT/INSTRUMENTS, COMPONENT LOCATIONS, AND ABBREVIATIOHS

7.1 PREREQUISITES

The following conditions shall exist at start of testing for that portion of the system being tested.

7.1.1 Systems have been inspected for compliance with construction documents.

7.1.2 Vendor data and operating instructions are at hand for each installed instrument, pump, and valve.

7.1.3 Reference documents (including this ATP) have been verified for correct revision number and outstanding ECNs.

7.1.4 A Job Safety Analys is has been prepared by ICF KH and a Prejob Safety Heeting has been conducted.

7.1.5 Test instruments have a valid calibration stamp attached. Test instrument identification numbers and calibration expiration dates have been recorded in Para 7.2 .

7.1.6 Methods of water disposal have been approved by facilities Management.

7.1.7 Power is available to energize the system. - Crecurt $\$ 24$ AT $244-5$

CIRCuIT $\neq 3$ hT $242-5$. CIRCuIT 5,7,8, AND 27 AT 219-5 | ECN 65

7.1.8 Annunciator lights have been tested." "Fuse at Aununciarive keon 3822.

7.1.9 Voice communications are available between 219-5, 222-S, 242-5, 244-S, leak detection sensor locations, and other locations determined to be appropriate by the test director.

7.1.10 Radiation Kork Permits (RHPs) have been approved by the Operating Contractor. Attach Rh'Ps to ATP.

7.1.11 Pump F1 spool piece is disconnected from Tank 102.- sea tect exception",

7.1.12 Project equipment and instruments have been identified by tag numbers.

7.1.13 Shop test results for Panels IPI, IP.2, and IP3 are on file, for record, with ATP/OTP.

\subsection{EQUIPMENT/INSTRUMENTS}

Supplied by Test Operator unless otherwise noted.

7.2.1 Voltohmmeters (VOM): $\frac{m .70}{48.45}$ Instrument No. $950-45-\operatorname{ce}-015$ Expiration Date $\frac{8-5-97}{7-26-97}$

7.2.2 Switchable Shorting Jumpers: length, 1 foot through 6 foot as required. 


\section{Appendix A}

7.2.3 Pressure Gages: $0-150$ psig. Pressure test assembly used for tank IECN 65 trailers may be used for this ATP.

7.2.4 Container: To hold water for leak detector tests, approximately l gallor capacity.

7.2.5 Tubing: 1/4-inch and 1/2-inch tygon.

7.3 COMPONENT LOCATION

\begin{tabular}{|l|c|}
\hline \multicolumn{1}{|c|}{ Component Identifier } & \multicolumn{1}{|c|}{ Location } \\
\hline Control Panel IP2 & $219-5$ \\
\hline Control Panel IP3 & $219-5$ \\
\hline $\begin{array}{l}\text { Hotor Operated Vaives HV-P1 } \\
\text { and HV-305 }\end{array}$ & $219-5$ \\
\hline Panelboard (219-5X) & \multicolumn{1}{|c|}{$219-5$} \\
\hline $\begin{array}{l}\text { Leak Detector Elements LDE-305A, } \\
306 B, 306 C\end{array}$ & $\begin{array}{l}\text { On the transfer piping between } \\
\text { Tank-102 and 244-S }\end{array}$ \\
\hline $\begin{array}{l}\text { Leak Detector Transmitters LOT-306A, } \\
306 B, 305 C\end{array}$ & $\begin{array}{l}\text { Outside, between 219-S and } \\
\text { 244-S }\end{array}$ \\
\hline Pushbuttons PERMIT and DENY & \begin{tabular}{l} 
Control Panel A in 242-S \\
\hline
\end{tabular}
\end{tabular}

7.4 ABBREVIATIONS

CASS Central Alarm Surveillance Systems

ECN Engineering Change Notice

LDE Leak Detector Element

LDT Leak Detector Transmitter

LoY Leak Detection Relay

Mov Motor-Operated Vaive

RWP Radiation Kork Permit 


\section{Appendix A}

This test will verify operation of the leak detection system consisting of LDE, leak detection processor, annunciation and control interlock. This system is based upon conductivity principle. When the liquid due to leak contacts both the ground probe and the leak detection probe of the LDE, leak detection relays deenergize and provide annunciation, local indication by beacon light, and interlock outputs.

\subsection{PREPARATION}

\begin{tabular}{|c|c|c|c|}
\hline \multicolumn{2}{|c|}{ 4.4-i.? m.x.B. } & 8.1.1 & Verify all prerequisites of Para 7.1 and 7.2 have been met.- see testera \\
\hline \multirow{2}{*}{$\begin{array}{l}\text { man } \\
4.49 \\
0 \times 40\end{array}$} & 30.2 .3 & 8.1 .2 & Notify 219-5, 222-5, 242-5, and 244-5 Building Managers, and SHIFT MA \\
\hline & $4-3-97$ & & \\
\hline \multirow[t]{4}{*}{$\begin{array}{l}2 \pi x-8 \\
104-97\end{array}$} & $\frac{M \cdot N \cdot B}{4-3-97}$ & 8.1 .3 & Notify Tank Farm Operations Hanager. \\
\hline & $m \cdot 2 \cdot B$ & 8.1 .4 & Verify that energized electrical work permits have been obtained. \\
\hline & & NOTE: & Keep appropriate personnel informed as to test status. \\
\hline & & CAUTION: & $\begin{array}{l}\text { TEST INVOLYES WORKING WITH LIVE CIRCUITS. ENSURE THAT THE IMMEDIATE } \\
\text { AREA IS NOT WET. ENSURE THAT HANDS AND APPAREL ARE DRY. }\end{array}$ \\
\hline
\end{tabular}

8.2 LEAK DETECTION AND MONITORING SYSTEM TEST

Record the following steps for each LDE/LDT loop on Data Sheet 8.2.

\subsubsection{Remove LDE from pipe.}

8.2.2 Apply power to monitoring units (Circuit 24,. Panelboard B at 244-5, Circuit 3 at Panelboard 242-S, and Circuit, 27 at 219-5).

8.2.3 Immerse LDE in liquid.

8.2.4 Verify white indicating beacon light at $244-5$ is on.

8.2.5 Verify contact $1-7$ of LDT in Panel IP2 at 219-S is CLOSED.

8.2.5 Verify Annunciator Window 1-1, ENCASEHENT LEAK on Panel A at 242-5 is FLASHING and audible alarm is ON.

8.2.7 Verify Annunciator Kindow 3-5, TRANSFER LINES TO 244-S On Panel IP3 at $219-5$ is FAST FLASH and audible alarm is ON.

8.2.8 Verify Group Annunciator AI-3B, Window 9, DRAIN LEAK DETECTION at 222-S Room $3 B$ is FLASHING and audible alarm is ON.

8.2.9-Verify leak-indieating light-at-LOF-on-Panel-iP2-is ON- ECN 65

8.2.10 Verify leak indicating light at Panel IP3 is ON.

8.2.11 Depress ACKNOWLEDGE pushbutton at 219-5 and verify Annunciator Window 3-5 is STEADY ON and audible al arm is OFF. 


\section{Appendix A}

8.2.12 Depress ACKNOWLEDE pushbutton at $242-5$ and verify Annunciator Window $1-1$ is STEADY ON and audible alarm is OFF.

8.2.13 Depress ACKNOWLEDGE pushbutton at 222-S, Room $3 B$ and verify Annunciator Window 9 is STEADY ON and audible alarm is OFF.

8.2.14 Remove LDE from liquid and dry it off.

8.2.15 Verify white indicating beacon light at 244-S is OFF.

8.2.16 Verify leak indicating light at LDT on Panel IP2 is OFF.

8.2.17 Verify Annunciator Window 3-5 at Panel IP3 is SLOW FLASH and audible a arm is ON.

8.2.18 Depress RESET pushbutton at Panel IP3 and verify Annunciator Window 3-5 and audible alarm are OFF:

8.2.19 Verify Group Annunciator A1-3B Window 9 at 222-S Room $3 B$ is OFF.

8.2.20 Verify Annunciator Hindow $1-1$ at 242-S is OFF.

3.2.20a DeEnergIzE CIRCuIT 24 an PANEL $B$ in 244.5

8.2.21 Reinstall LDE in pipe.

ECN 65

$8.221 a$ ENERgIEE CIRCMIT 24 ON PANEL DIN 2445 
Appendix A

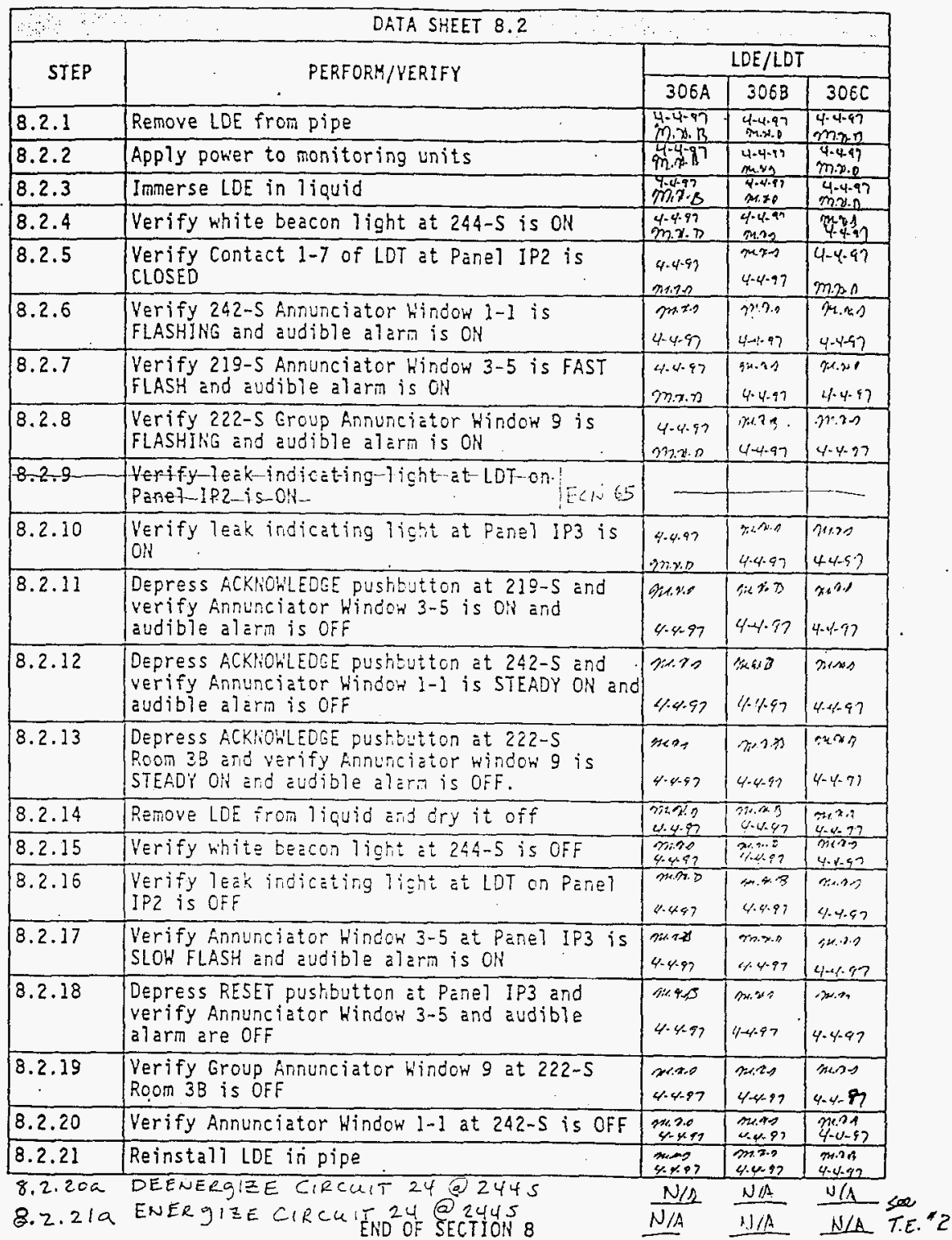




\section{Appendix A}

9 TRANSFER PUMP PI SPEED CONTROL

This test will verify speed control operation of Pump P-1 in 219-5.

\subsection{PREPARATION}

N/A 9.1.1 Verify all prerequisites of Para 7.1 and 7.2 have been met.

N/A 9.1.2 Notify 219-S and 242-S Building Managers.

N/A 9.1.3. Notify Tank Farms Operations and Shift Manager.

N/A 9.1.4 Verify that energized electrical work permits have been obtained.

NOTE: Keep appropriate personnel informed as to test status.

CAUTION: TEST IHYOLYES WORKIHG HITH LIVE CIRCUITS. EHSURE THAT THE IKKEDIATE AREA IS HOT HET. EHSURE THAT HANDS AND APPAREL ARE DRY.

9.2 TRAKSFER PUHP PI SPEED CONTROL TEST

D/A 9.2.1 Verify Air Vatve CA-V-6600 is CLOSED.

N/A 9.2.2 Energize Circuit 3 for Panel A from Panelboard 6 at $242-5$.

N/A 9.2.3 Energize Panels IP2 and IP3 at 219-S.

N/A 9.2.4 Pull to reset DENY switch.

N/A 9.2.5 Fress and release PERMIT pushbutton.

N/A 9.2.6 Verify TRANSFER PUHP $P-1$ indicating ight on $242-5$ is oN.

N/A 9.2.7 Rotate pump speed control knob to $0 \%$ position.

CAUTIOH: High pressure air way be present. Perform following operation slowly.

N/A 9.2.8 Disconnect instrument air tubing at the outlet of Regulator HY301.

N/A 9.2.9 Instail a tee fitting between the regulator outlet and the process tubing. Connect an instrument pressure gauge to the remaining end of the tee fitting.

NOTE: Readings taken from this pressure gauge, and recorded in this ATP/OTP, are for information only and have no bearing on the acceptance of this test.

N/A 9.2.10 Verify Valve HV-305 OPEN (red) indicating light on Panel IP3 is ON and Valve HV-P] CLOSED (green) indicating light on Panel IP3 is ON.

N/A 9.2.11 Verify pump speed control knob is turned to $0 \%$ position.

NIA 9.2.12 Apply porier to the electropneumatic controller (Circuit 8 at 219-5X).

N/A 9.2.13 Open Air Valve CA-V-6600.

* Ref. OTP dated 10-14.97 


\section{Appendix A}

W/A 9.2.14 Record reading on the pressure gauge.

psi

N/A 9.2.15 Turn Kand Switch KS-305 to CLOSE position and hold while verifying the following.

N/A 9.2.15.1 As the valve travels toward the closed position, verify both OPEN (red) and CLOSED (green) indicating lights are ON.

N/A 9.2.15.2 when the valve reaches the fully closed position, verify OPEN indicating light is OFF and CLOSED indicating light is OH.

N/A 9.2.16 Release Hand Switch HS-305 to AUTO position.

N/A 9.2.17 Turn Hand Switch HS-Pl to OPEN position and hold while verifying the following.

N/A 9.2.17.1 As the valve travels toward the open position, verify both open (red) and CLOSED (green) indicating lights are ON.

N/A 9.2.17.2 then the valve reaches the fully open position, verify CLOSED indicating light is OFF and OPEN indicating light is OH.

N/A 9.2.18 Release Hand Switch HS-Pl to RUTO position.

N/A 9.2.19 Slowly rotate pump speed control knob clockwise to $50 \%$ position.

N/A 9.2 .20 . Record reading on the pressure gauge. psi

NOTE: This reading should be higher than that taken with pump speed control knob at $0 \%$.

N/A 9.2.21 Slowly rotate puim speed control knob to $100 \%$ position.

N/A - 9.2.22 Record reading on the pressure gauge. psi

HOTE: This reading should be higher than that taken with pump speed control krob at $50 \%$.

W/A - 9.2.23 Slowly rotate pump speed control knob back to $0 \%$ position.

N/A 9.2.24 Record reading on the pressure gauge. psi.

HOTE: This reading should be approximately the same as that taken when pump speed control knob was first at o\% position.

N/A 9.2.25 Turn Hand Switch HS-P1 to CLOSE position and verify the following.

N/A 9.2.25.1 As the valve travels toward the closed position, verify both opeN and CLOSED. indicating lights are ON.

N/A 9.2.25.2 When the valve reaches the fully closed position, verify CLOSED indicating light is ON and OPEN indicating light is OFF.

NIA 9.2.25.3 Verify the closing of Vaive HV-PI has caused Valve HV-305 to OPEN.

N/A 9.2 .26 Close Air Valve CA-V-6600.

* Ref. OTP dated 10-14-9t 
Appendix A

CAUTION: HIGH PRESSURE AIR MAY BE PRESENT. PERFORH FOLLOWIHG OPERATION SLOWLY.

N/A 9.2.27 Reconnect the tubing to outlet side of Regulator HY301.

N/A 9.2.28 Remove power from Regulator HY301.

* Ref. OTP dated $10.14-96$

$m \cdot s$

END OF SECTION 9

$9-3,47$ 
These tests will verify that Motor Operated Valves HV-Pl and HV-305 operate in accordance with their respective elementary (control) diagram requirements.

HV-Pl is contralled by a 3 position (OPEN-AUTO-CLOSE) control switch which can be maintained in either AUTO or CLOSE pOsition but will spring-return from OPEN to AUTO.

HV-305 is controlled by a 3 position (CLOSE-AUTO-OPEN) control switch which can be maintained in either AUTO or OPEN position but will spring-return from CLOSE to AUTO.

Operation of HV-PI is dependent on the operation of HV-305. HV-Pl is designed as automatic CLOSE and manual override CLOSE while HV-305 is designed as automatic OPEN and manual override OPEN. In other words, HV-PI will not OPEN unless HV-305 is CLOSED.

\subsection{PREPARATION}

N/A 10.1.1 Verify all prerequisites of Para 7.1 and 7.2 have been met.

N/A 10.1.2 Kotify 219-S and 242-5 Building Kanagers.

N/A 10.1.3 Notify Tarik Farm Oparations and Shift Manager.

N/A 10.1.4 Verify that energized electrical hork permits have been obtained.

NOTE: Keep appropriate personnel informed as to test status.

CAUTIOH: TEST INYOLVES WORKING WITH LIVE CIRCUITS. ENSURE THAT THE IKHEOIATE AREA IS NOT WET. ENSURE THAT HANDS AND APPAREL ARE DRY.

10.2 MOTOR OPERATED VALVE HV-PI AND HV-305 TEST

N/A 10.2.1 Place Circuit Breaker 7 in Panelboard 219-5x, at Euildirg 2jg-S, in the OFF position.

N/A 10.2.2 Verify there is fO VOLTAGE across Teminals TE2-2C5 and TB2-200 at Panel IP3.

N/A 10.2.3 Place Circuit Breaker 7 in Panelboard 219-5X, at Euilding 219-5, in the on position.

N/A 10.2.4 Place Circuit Ereaker 27 in Panelboard 219-5, at Euilding 219-5, in the or position.

N/A 10.2.5 Place Circuit No. 3 in Panelboard $C$, at Building 242-5, in the ON position.

N/A 10.2.6 Verify DENY pushbutton in Panel A, at Building $242-5$, is in PULL TO RESET position.

N/A 10.2.7 Press and release PERMIT pushbutton in Panel A at Building 242-5.

W/A 10.2.8 Using VOM verify $120 \mathrm{~V}$ ac across Terminals TB2-201 and TB1-7N2.

* Ref. OTP dated 10-14.9\% 


\section{Appendix A}

N/A 10.2.9 Verify PERMITIED indicating light on Panel IP3 is . ON.

N/A. 10.2.10 Verify TRANSFER PUMP $P-1$ indicating Tight on Panel $A$, in 242-S, is ON.

N/A 10.2.11 Turn selector switch for Valve HV-305 on Panel IP3 to OPEN.

N/A 10.2.12 Verify Valve KV-305 position handle at top of valve actuator indicates OPEN and valve CLOSED (green) indicating light on Panel IP3 is OFF and valve OPEN (red) indicating light is ON.

N/A_ 10.2.13 Turn selector switch for Valve HV-PI on Panel IP3 to CLOSE.

N/A 10.2.14 Verify valve KV-P1 position handle at top of valve actuator indicates CLOSE and valve CLOSED indicating light on Panel IP3 is ON.

N/A 10.2.15 Using VOM verify Relay $K-V$ on Panel IP2 is ENERGIZED.

N/A 10.2.16 Turn selector switch for HV-P1 from CLOSE to AUTO.

N/A 10.2.17 Verify Valve HV-Pl position handle at top of valve actuator continues to indicate CLOSE and valve CLOSED indicating light on Panel IP3 remains of.

N/A 10.2.18 Turn and hold selector switch for HV-Pl in OPEN position.

N/A 10.2.19 As Valve HV-PI travels toward the open position; verify both OPEN and CLOSED indicating lights are ON.

N/A 10.2.20 When Valve HV-PI reaches the fully open position, verify CLOSED indicating light is OFF and OPEN indicating light is ON.

N/A_ 10.2.21 Release selector switch for HV-F1. to AUTO.

N/A 10.2.22 Verify Valve HV-Pl begins to close.

N/A 10.2.23 As Valve HV-PI travels toward the closed position, verify both oPEN and CLOSED indicating lights are ON.

N/A 10.2.24 When Valve HV-P1 reaches the fully closed position, verify OPEN indicating light is OFF and CLOSED indicating light is oN.

N/A 10.2.25 Turn and hold selector switch for HV-305 in CLOSE position.

N/A 10.2.26 As Valve HV-305 travels toward the closed position, verify both OPEN and CLOSED indicating lights are ON.

N/A 20.2.27 When valve position handle on Valve HV-305 shows fully closed, verify CLOSED indicating light is ON and OPEN indicating light is OFF.

N/A 10.2.28 Release selector switch for HY-305 to AUTO position.

N/A 10.2.29 Turn and hold selector switch for HW-Pl in OPEN position.

N/A 10.2.30 As Valve HV-PI travels toward the open position, verify both OPEN and * Ref OTP dated $10.16-96$ CLOSED indicating lights are ON. 


\section{Appendix A}

N/A 10.2.31 When valve position handle on Valve HV-P1 shows fully open, verify OPEN indicating light is ON and CLOSED indicating right is OFF.

N/A 10.2.32 Release selector switch for HV-P1 to AUTO position.

N/A 10.2.33 Turn selector switch for HV-305 to OPEN position.

N/A 10.2.34 Verify Valve HV-305 starts to OPEN.

N/A 10.2.35 Verify HV-P1 begins to CLOSE as soon as HV-305 is fully OPEN.

N/A 10.2.36 Turn and hold selector switch for HV-305 in CLOSE position until HV -305 is CLOSED and then release selector switch to AUTO position.

N/A 10.2.37 Turn and hold selector switch for HV-P1 in OPEN position untit HV-P1 is OPEN.

N/A 10.2.38 Depress DEHY switch to Push to Deny position on Panel A in 242-S Control Roon.

N/A 10.2.39 Verify PERMITTED indicating light on Panel IP3 is OFF.

$N / A$ 10.2.40 Verify TRANSFER PUHP $P$ - i indicating light on Panel $A$ in $242-5$ is OFF.

N/A 10.2.41 Pull DENY switch to Pull to Reset position on Panel A in 242-S.

N/A 10.2 .42 Verify HV-PI starts to CLOSE.

N/A 10.2.43 Verify HV-305 begins to OPEN as soon as HV-Pl is fully CLOSED.

N/A 10.2.44 Using VOH verify Relay K-P on Panei IP2 is ENERGIZED.

N/A 10.2.45 Verify HV-305 position handle at top of valve actuator is in OPEN position.

* Ref. OTP dated $10.14 .96^{\circ}$

$M \cdot 0 . B$

4.3 .97

EHO OF SECTION 10 


\section{Appendix A}

11

INTEGRATED SYSTEM (DRY) TEST AND INTERLOCK VERIFICATION

This test will demonstrate overall system operation by verifying the various interlocks perform the design functions. During this test no liquid will be pumped out of the tanks. Pump vendor assures that the pump can be run "DRY" for certain time duration.

11.1 PREPARATION

N/A 11.1.1 Verify all prerequisites of Para 7.1 and 7.2 have been met.

N/A 11.1.2 Notify 219-S, 222-S, 242-5, and 244-5 Building Managers.

N/A 11.1.3 Notify Tank Farm Operations and Shift Manager.

N/A 11.1.4 Verify that energized electrical work permits have been obtained.

MOTE: Keep appropriate personnel informed as to test status.

N/A 11.2.5 Verify all previous ATP sections have been completed satisfactorily.

11.2 SYSTEM TEST

N/A 11.2.1 Verify Pariel IP2 is EHERGIZED.

N/A 11.2.2 Verify Panel IP3 is EliERGIZED.

N/A 11.2.3 Verify Panel $A$ in 242-5 is EIFERGIZED.

N/A 11.2 .4 Close Air Inlet Valve CA-V-6500.

N/A 11.2.5 Verify OENY switch in Panel A at 242-S is in Pull to Reset position.

N/A 11.2 .6 Press and release PERHIT pushbutton in Panel A at $242-5$.

N/A 11.2.7 Verify TRAilSFER PUHP P-1 indicating light at Panel A $242-S$ is OH.

N/A 11.2.8 Verify PEFMITTED indicating light on Panel IP3 is O.l.

N/A - 11.2.9 Verify Siphon VaTve HV-305 is OPEN.

$\mathrm{N} / \mathrm{A}$ 11.2.10 Verify leak detection indicating light on panel IF2 is OFF.

$N / A \quad 11.2 .11$ Verify leak detection indicating light on Panel ip 3 is ofF.

N/A 11.2.12 Verify pump diaphragm leak indicating light on Panel IP3 is OFF.

N/A 11.2.13 Verify Pump PI (air inlet) hand switch on Panel IP3 is in CLOSE position.

N/A_11.2.14 Turn HV-Pl hand switch to OPEN and hold it momentarily in that position.

N/A 11.2.15 Verify KV-PI begins to OPEN as indicated by both RED and GREEN indicating lights $\mathrm{ON}$.

* Ref. OTP dated 10.14-96

on. 21. B 4-3-97 


\section{Appendix A}

N/A 11.2.16 Release HV-Pl hand switch allowing it to return to AUTO.

N/A 11.2.17 Verify HV-Pl begins to Close.

N/A 11.2.18 Close siphon Valve HV-305 by turning control switch on Panel IP3 to CLOSE.

N/A 11.2.19 Release Hand Switch for HV-305 allowing it to return to AUTO.

N/A 11.2.20 Verify HV-305 is CLOSE as indicated by indicating light.

N/A 11.2.21 Open Air Valve CA-V-6500.

N/A 11.2.22 Turn and hold HV-PI hand switch on Panel IP3 to OPEN.

N/A 11.2.23 Verify Pump PI STARTS as indicated by indicating OPEN light.

N/A 11.2.24 Release HV-Pl hand switch to AUTO.

N/A 11.2.25 Verify Pump PI continues to run as indicated by indicating OPEK light.

N/A 11.2.26 Simulate leak by connecting shorting jumper at Terminals TB2-207 and TB2-208 on Panel IP3.

N/A 11.2.27 Verify Punp P1 air inlet valve starts to CLOSE.

N/A 11.2.28 Verify Siphon Valve HV-305 starts to OPEN as soon as Pump P1 STOPS.

N/A 11.2.29 Remove shorting jumpers at Terminals TB2-207 and TB2-208.

N/A 11.2.30 Verify Pump Pl remains STOPPED.

N/A 11.2.31 Stät CLOSIKG Siphon Valve HV-305.

N/A 11.2.32 Turn Punp Pl hard siritch to OPEll as soon as Siphon Valve HV-30s has closed.

N/A 11.2.33 VETIYY PUTP PI STARTS.

N/A 11.2.34 Release Pump P1 hand switch to AuTo.

N/A 11.2.35 Verify Pump Pl continues to run as indicated by open light.

N/A 11.2.36 Depress DEkY switch to Push to Deny position at 242-S Panel A.

N/A 11.2.37 Verify Pump Pl cannot START when Pump Pl hand switch is turned to OPEN.

N/A 11.2.38 Verify Siphon valve is OPEN as indicated by indicating light oN.

N/A 11.2.39 Pull DENY switch to Pull to Reset position.

N/A 11.2.40 Close siphon Valve HV-305.

N/A 11.2 .41 Press and release PERMIT pushbutton at 242-S Panel A.

* Ref. OTP dated 10:14-96 


\section{Appendix A}

NLA 11.2.42 Verify TRARSFER PUMP P-1 indicating light is on at 242-5 Panel A.

N/A 11.2.43 Verify PERMITTED indicating light on Panel IP3 is ON.

N/A 11.2.44 Verify Pump PI STARTS by turning HV-PI hand switch on Panel IP3 to OPEN.

N/A 11.2.45 Simulate pump diaphragm leak.by connecting shorting jumper at Terminats TB2-205 and TB2-206.

N/A 11.2 .46 Verify Pump Pl air inlet valve starts to CLOSE.

NI/A 11.2.47 Verify Siphon Valve HW-305 starts to OPEN as soon as Pump PI STOPS.

N/A 11.2 .48 Remove shorting jumpers at Terminals TB2-205 and TB2-205.

N/A 11.2 .49 Close air valve $C A-Y-6600$.

* Ref OTP dated 10.14-97

END OF SECTION 11 


\section{Appendix A}

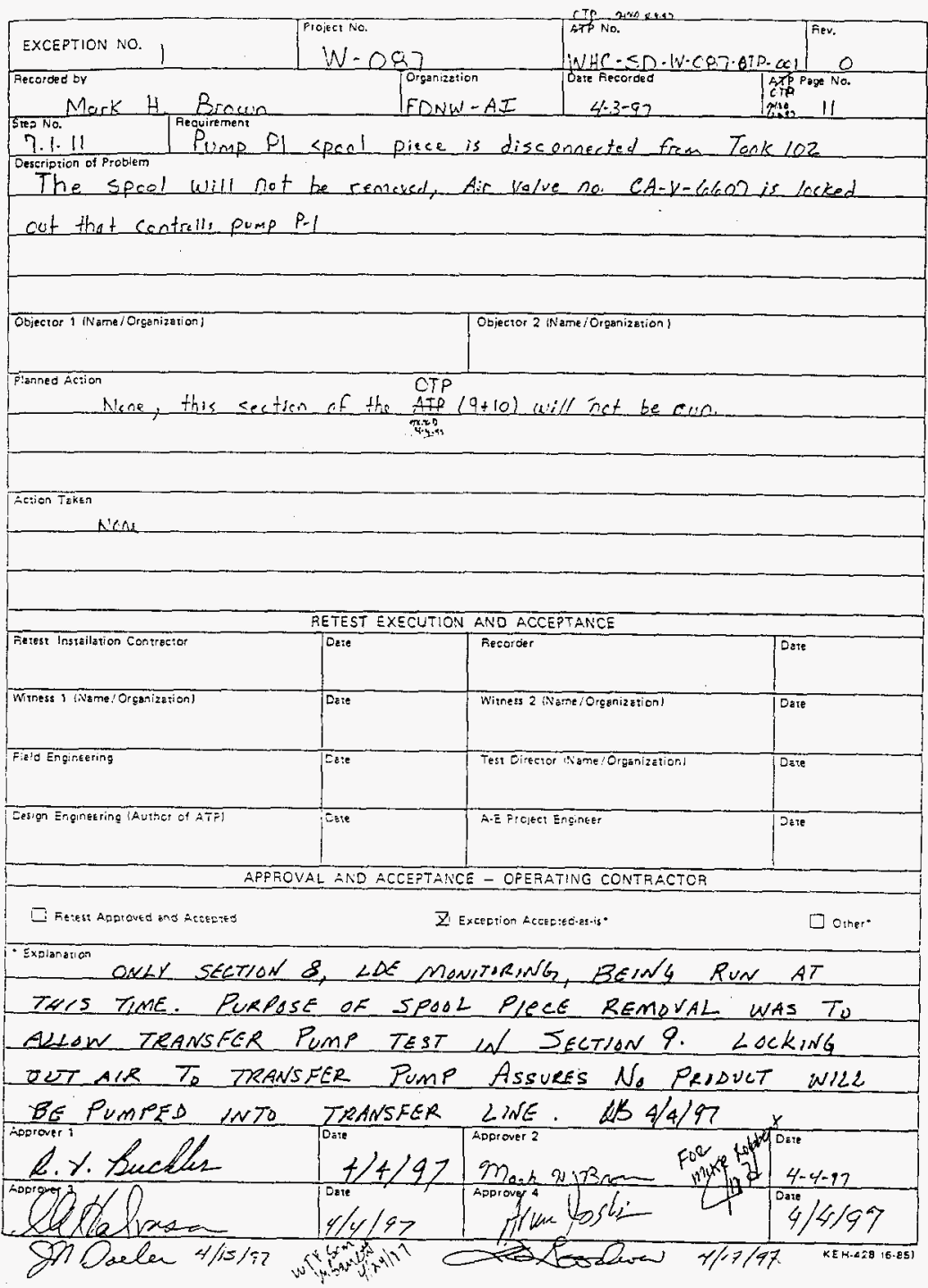




\section{Appendix A}

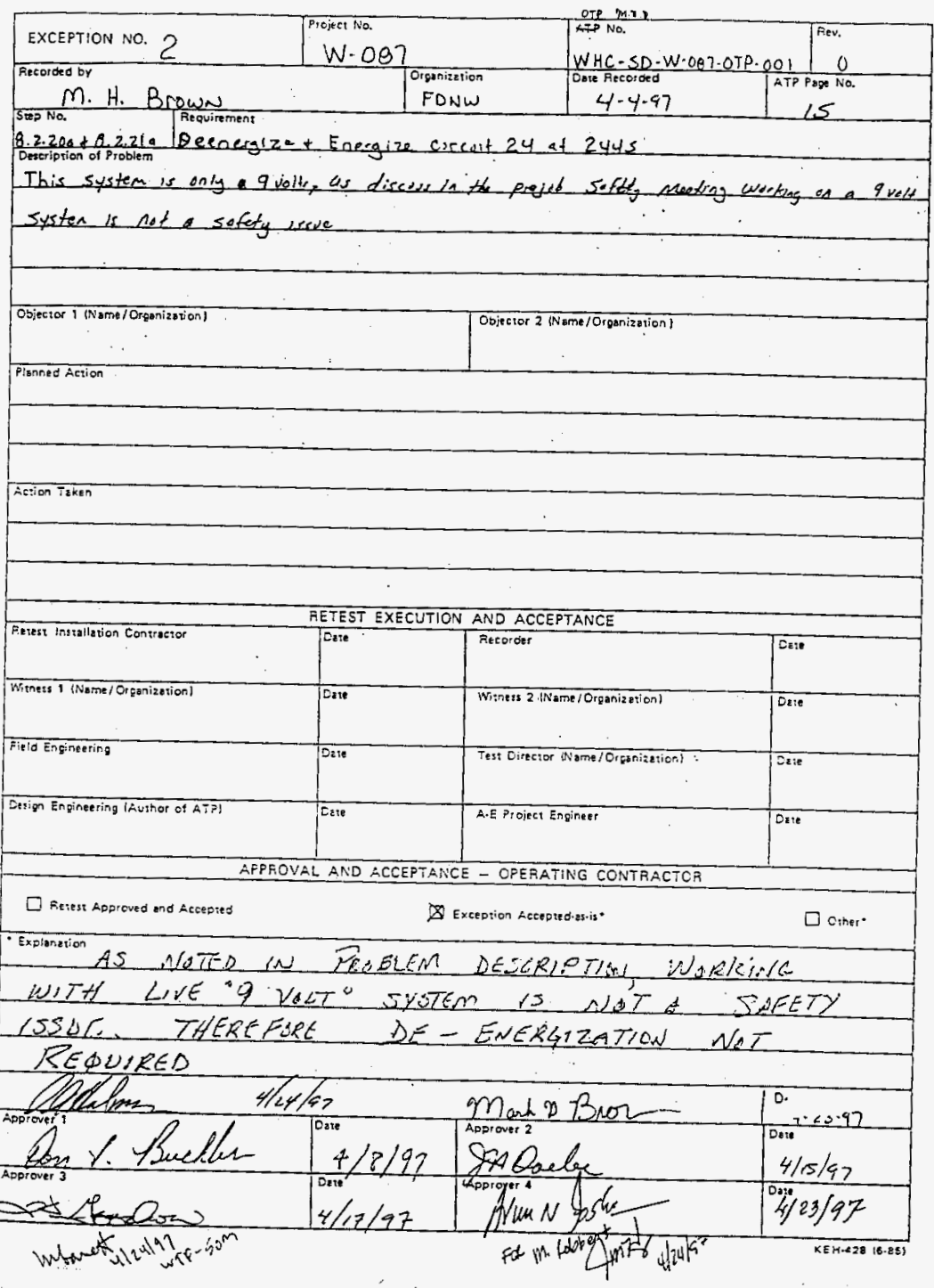

